\title{
Kahramanmaraş Sütçü İmam Üniversitesi, Avşar Yerleşkesi Tohumlu Bitkilerinin Çeşitliliği
} ve Sistematiği

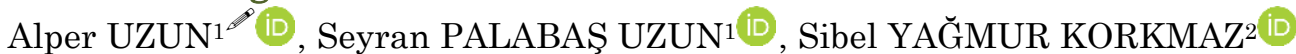 \\ ${ }^{1}$ Kahramanmaraş Sütçü İmam Üniversitesi, Orman Fakültesi, Orman Mühendisliği Bölümü, Kahramanmaraş, ${ }^{2}$ Kahramanmaraş Sütçü İmam \\ Üniversitesi, Fen Bilimleri Enstitüsü, Orman Mühendisliği Anabilim Dalı, Kahramanmaraş
}

\section{ÖZET}

$\mathrm{Bu}$ çalışma Kahramanmaraş Sütçü İmam Üniversitesi, Avşar yerleşkesi tohumlu bitki çeşitliliğini belirlemek ve sistematiğinin oluşturulması amacıyla yapılmıştır. Araştırma alanı Kahramanmaraş ili sınırları içinde ve Davis'in karelaj (Grid) sistemine göre C6 karesinde yer almaktadır. Bu araştırmada, Nisan 2016 - Haziran 2017 tarihleri arasında yapılan arazi çalışmalarında toplanan bitki örnekleri değerlendirilmiş ve 65 familya, 194 cinse ait 279 tohumlu bitki taksonu tespit edilmiştir. Bu taksonlardan 2 adeti (\% 0.71) (Papaver clavatum, Trigonella kotschyi) Türkiye için endemiktir. Ayrıca Türkiye için endemik olup yalnızca Muğla ve çevresinden bilinen Liquidambar orientalis var. orientalis taksonu yerleşke içerisinde ex-situ olarak bulunmaktadır. Fitocoğrafik bölgesi belirlenebilen taksonların 21’i (\% 7.5) İran - Turan bölgesine, 10’u (\% 3.5) Avrupa - Sibirya bölgesine, 54'ü (\% 19.3) Akdeniz bölgesine dâhildir. Çok bölgeli veya bölgesi bilinmeyen 194 takson ise \% 69.5 oranına sahiptir. En çok taksona sahip familyalar, Fabaceae 54 takson (\% 19.4), Asteraceae 29 takson (\% 10.4), Poaceae 21 takson (\% 7.5), Rosaceae 11 takson (\% 3.9), Apiaceae ve Brassicaceae ise 10'ar taksona (\% 3.6) sahiptir.
DOI:10.18016/ksutarimdoga.vi.452854

\section{Makale Tarihçesi}

Geliş Tarihi : 30.03.2018

Kabul Tarihi : 20.06.2018

\section{Anahtar Kelimeler \\ Tohumlu bitkiler, \\ Flora, \\ Avşar yerleşkesi, \\ KSÜ, \\ Kahramanmaraş}

\section{Araştırma Makalesi}

\section{Diversity and Systematics of Seed Plants in Avşar Campus, Kahramanmaraş Sütçü İmam University (KSU)}

\begin{abstract}
This study was conducted in order to determine the seed plant diversity and systematics of Avşar Campus, Kahramanmaraş Sütçü İmam University (KSU). The research area was located within the borders of Kahramanmaraş province and C6 according to Davis' square (Grid) system. In this study, plant samples that were collected during the field studies conducted between April 2016 and June 2017 were evaluated. Total of 279 seed plant taxa belonging to 194 genera of 65 families were determined. Two of these taxa (0.71\%) (Papaver clavatum, Trigonella kotschyi) were endemic to Turkey. Also, Liquidambar orientalis, which is relict endemic taxon known only from Muğla and its environs, is found as planted for ex-situ conservation within the campus. Twenty-one $(7.5 \%)$ of the taxa that can be identified phytogeographical region belong to Irano-Turanian region, 10 taxa (3.5\%) belong to Euro-Siberian region and 54 taxa (19.3\%) belong to Mediterranean region. 194 taxa, which are multiregional or unknown, have a ratio of $69.5 \%$. The richest families including Fabaceae with 54 taxa (19.4\%), Asteraceae with 29 taxa (10.4\%), Poaceae with 21 taxa (7.5\%), Rosaceae with 11 taxa (3.9\%), Apiaceae and Brassicaceae with 10 taxa each (3.6\%) were determined.
\end{abstract}

Article History

Received : 30.03.2018

Accepted : 20.06.2018

\section{Keywords}

Seed plants,

flora,

Avşar campus,

KSU,

Kahramanmaraş

Research Article

To cite: Uzun A, Palabaş Uzun S, Yağmur Korkmaz S 2018. Diversity and Systematics of Seed Plants in Avşar Campus, Kahramanmaraş Sütçü İmam University (KSU). KSÜ Tar Doğa Derg 21(6) : 854-874, DOI:10.18016/ksutarimdoga.vi.452854 


\section{GİRIŞ}

Türkiye dünyada zengin floraya sahip ülkelerden biridir. Aynı zamanda Ilıman kuşak içerisinde yer alır. Bitki çeşitliliği açısından çevresinde yer alan birçok ülkeden farklı olan özelliklere sahiptir. Türkiye'de yayılış gösteren bitki türlerinin sayısı, Avrupa kıtasının tümünde yayılış gösteren bitki türlerinin sayısına yakındır (Erik ve Tarıkahya, 2004, Avcı, 2005). Türkiye Florasının 1/3 kadarının da endemik bitkilerden oluşması, bu çeşitliliğin korunması anlamında büyük değer ifade etmektedir (Başer, 2000; Avc1, 2005).

Ülkemiz florası hakkında bilgiler sunan ilk eser 18651888 yılları arasında İsviçreli botanikçi Pierre Edmond Boissier (1810 ile 1885 yılları arasında yaşamıştır) tarafından yazılan Flora Orientalis'tir. Bu kitaptan tam yüzyıl sonra, yazıldığı dönemde dünyanın en iyi ve kapsaml floralarından biri olan "Türkiye ve Doğu Ege Adaları Florası / Flora of Turkey and The East Aegean Islands" adlı eser İngiliz Botanikçi Prof. Peter Hadland Davis editörlüğünde dokuz esas ve bir ek cilt halinde 1965-1988 yılları arasında yayınlanmıştır (Davis ve ark., 1965-1985, Davis ve ark., 1988). Aynı eserin ikinci ek cildi de Türk botanikçilerin editörlüğünde 2000 yılında tamamlanmış ve yine Edinbugh Üniversitesi tarafından yayınlanmıştır (Güner ve ark., 2000).

11 cildin yayınlanması ve yeni türlerin de ilavesi ile birlikte Türkiye florasının bitki türü sayısı 9753 'e ve toplam takson sayısı ise 11.707'e ulaşmıştır (Güner ve ark., 2012). Bu taksonlardan, 3035 tür endemik olup, toplam endemik takson sayısı 3649 (\% 31)'dur. Son yıllarda yapılan flora ve revizyon çalışmaları ile birlikte Türkiye Florasına yeni taksonlar eklenmiştir. Yakın zamanda modern taksonomi biliminde, özellikle moleküler biyolojik çalışmaların da devreye girmesi ile bitkilerin sınıflandırılmasında bazı köklü değişiklikler de meydana gelmiştir.

Kahramanmaraş ili nesli tehdit altındaki tür yoğunluğu bakımından Akdeniz Biyoçeşitlilik Sıcak Noktası sınırları içerisinde kalmaktadır. Aynı zamanda sahip olduğu farklı iklim geçişleri, farklı fitocoğrafik bölgelere yakınlığı ve Anadolu Diyagonali üzerinde bulunması nedeniyle zengin bitki ve habitat çeşitliliğine de ev sahipliği yapmaktadır. Bu nedenle de geçmişten günümüze yerli ve yabancı araştırmacıların mutlak uğrak noktalarından biri olmuştur.

Bu çalışma ile; (1) Kahramanmaraş Sütçü İmam Üniversitesi Avşar yerleşkesi doğal ve egzotik tohumlu bitkilerinin detaylariyla belirlenmesi, (2) İnternet tabanlı sanal yerleşke florasının oluşturulmasına katkı sağlanması, (3) Elde edilen veriler neticesinde yerleşke alanında tehdit altında türün bulunup bulunmadığının tespiti ve IUCN tehlike kategorilerinin [CR; Çok Tehlikede, EN; Tehlikede, VU; Zarar Görebilir, NT; Tehdit Altına Girebilir, LC; En Az Endişe Verici, DD; Veri yetersiz] belirlenmesi amaçlanmıştır. Çalışma sonunda doğal bitki elementlerinin varlığı dikkate alınarak, yerleşkede yapılacak tüm faaliyetlerin planlanmasinda bu türlerin korunması ve kullanılması gerekliliği konusuna da dikkat çekilecektir.

\section{ÇALIŞMA ALANI}

\section{Coğrafi Konumu}

Kahramanmaraş'ın büyük bir bölümü Akdeniz Bölgesi'nin Adana Bölümü'nde yer alırken, Elbistan ve Afşin ilçeleri Doğu Anadolu Bölgesi'nin Yukarı Fırat Bölümü içerisinde kalır. $\mathrm{Bu}$ özelliği ile Kahramanmaraş, Akdeniz Bölgesi ile Doğu ve Güneydoğu Anadolu Bölgeleri'nin birbirleriyle birleştiği bir bölümde bulunmaktadır (Karabulut ve Cosun, 2009).

Kahramanmaraş, kuzeyden Sivas, batıdan Kayseri ve Adana, doğudan Malatya ve Adıyaman, güneyden Osmaniye ve Gaziantep ile çevrilidir (Şekil 1). Kahramanmaraş İli, $37^{\circ} 11^{\prime}$ ve $38^{\circ} 36^{\prime}$ kuzey enlemleri ile $36^{\circ} 15^{\prime}$ ve $37^{\circ} 42^{\prime}$ doğu boylamları arasında yer almaktadır. Yüzölçümü ise $14.346 \mathrm{~km}^{2}$ 'dir (Anonim, 2005).

Kahramanmaraş'ın büyük bir bölümü dağllktır. Kuzeyde Orta Torosların devamı olan Binboğa Dağları $(2830 \mathrm{~m})$ yer alır. Güneydoğu Toros dağ sistemlerine ait dağlardan en güneydeki Kahramanmaraş Ovası'nın kuzeyinde yer alan Ahir Dağgı'dır (2301 m). Bunun kuzeyinde Engizek Dağ ${ }_{1}(2814 \mathrm{~m})$, Berit Dağı $(2917 \mathrm{~m})$, ve 3000 m’yi geçen Nurhak Dağları (Killi Tepe; $3075 \mathrm{~m}$ ) bulunur. Güneyde ise Amanos dağ sistemlerine bağlı Karlık (2061 m) ve Başkonuş dağları (1775 m) bulunur (Gürbüz, 2001). Ceyhan Nehri ve Aksu Erkenez, Göksu, Göksun, Hurman, Söğütlü Çayları, Fırnıs, Körsulu, Tekir Dereleri ile Andırın ve Keşiş Suyu il sınırları içerisindeki başlıca akarsulardır. Ovalar ise Kahramanmaraş, Elbistan, Göksun, Sağlık ve Narlı ovalarıdır (Anonim, 2005).

Araştırma alanı olarak seçilen Kahramanmaraş Sütçü İmam Üniversitesi yerleşke alanı, Kahramanmaraş il sınırları içinde Kayseri karayolu üzerinde kalmaktadır. Çalışma alanı, Davis (1965)'in Türkiye'yi karelendiren grid sistemine göre C6 karesinde yer almaktadır (Şekil 2). Calışma alanı coğrafi konum itibariyle $36^{\circ} 47^{\prime}-36^{\circ} 50^{\prime}$ boylamları ile $37^{\circ} 35^{\prime}-36^{\circ} 34^{\prime}$ enlemleri arasında bulunmaktadır. Çalışma alanının yüksekliği $484 \mathrm{~m}$ ile $563 \mathrm{~m}$ arasında değişmektedir. 


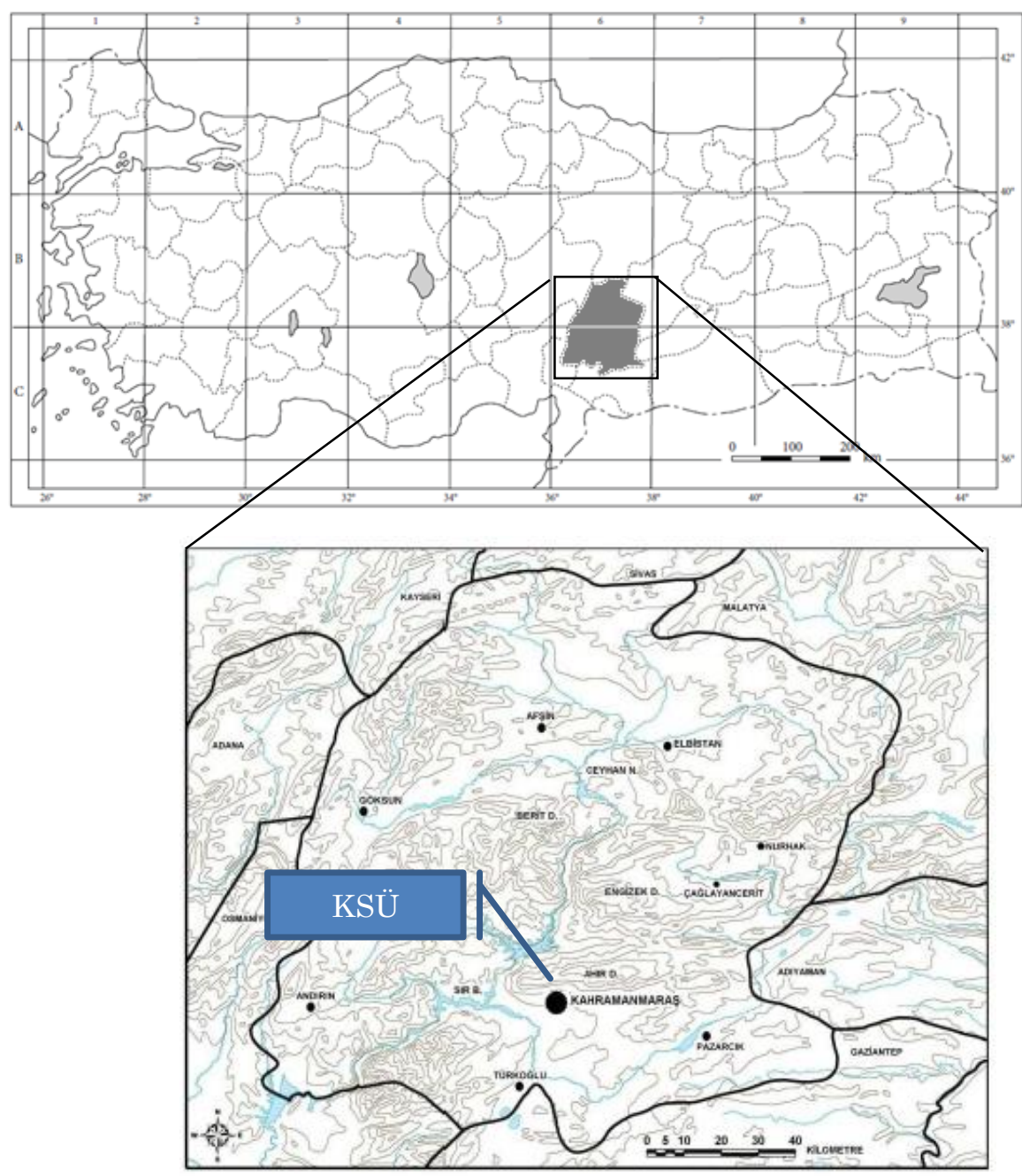

Şekil 1. Kahramanmaraş ilinin lokasyon haritası (Karabulut ve Cosun, 2009'dan değiştirilerek)

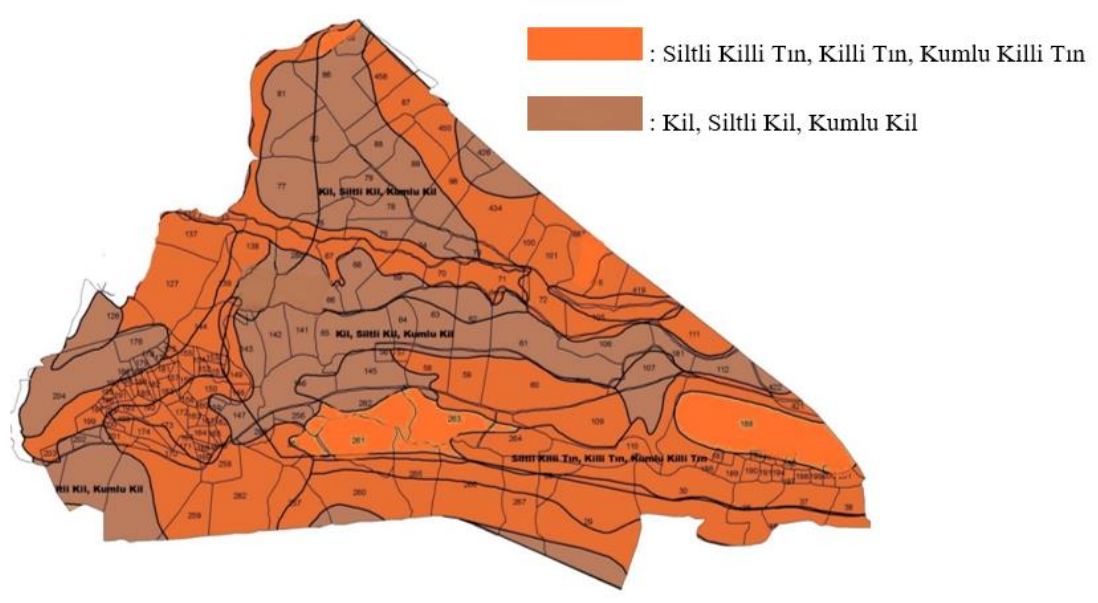

Şekil 2. KSÜ Avşar yerleşkesi toprak tekstürü haritası (Gündoğan ve ark., 1998)

Genel Toprak Yapısı ve Jeolojisi

İl genelinde; iklim, topografya ve ana madde farklılıkları sebebiyle zamana bağlı olarak çeşitli büyük toprak grupları oluşmuştur. Büyük toprak gruplarının yanı sıra toprak örtüsünden yoksun bazı arazi tipleri de bulunmaktadır (Anonim, 1997).
Alüvyal topraklar: Yüzey sularının tabanlarında veya tesir sahalarında akarsular tarafindan taşınarak yığılmış bulunan genç sedimentler üzerinde yer alan; düz ve düze yakın meyile sahip, (A) $\mathrm{C}$, profili azonal genç topraklardır. Alansal olarak 76.625 ha yayılım göstermektedir. Kolüvyal topraklar: Yer çekimi yüzey akışı, toprak kayması ve yan derelerle taşınarak biriken 
materyaller üzerinde oluşmuş (A) C profili genç topraklardır. Koluvyal topraklar il çapında 99.306 hektarlık bir alanda yayılım göstermektedir. Organik topraklar: Profilinde yüksek derecede organik madde muhtevasına sahip olan topraklardır. Organik topraklar il çapında toplam 2982 hektarlık alanda yayılım göstermektedir. Kahverengi orman topraklari: Kahverengi orman toprakları kireçce zengin ana madde üzerinde oluşur. Bu tip topraklar il çapında 348.826 hektarlık alanda yayılım göstermektedir. Kireçsiz kahverengi orman topraklari: A (B) C profili olan bu toprakların A horizonu iyi oluşmuştur ve gözenekli bir yapıya sahiptir. Kireçsiz kahverengi orman toprakları il çapında 135.195 hektarlık bir alanda yayılım göstermektedir. Kırmızı kahverengi topraklar: Solumun rengi hariç, hemen hemen diğer bütün özellikleri kahverengi topraklarm ayn veya benzeridir. $\mathrm{Bu}$ tip topraklarda il çapında 42.214 hektarlık bir alanda yayılım göstermektedir. Kahverengi topraklar: Kalsifikasyon olayma sahip olup ABC profili zonal topraklardır. Kalsifikasyon olayı sonucu profillerinde çok miktarda kalsiyum bulunur. Kahverengi topraklar il çapında 214.555 hektarlı alanda yayılım göstermektedir. Kireçsiz kahverengi topraklar: A (B) C profilli topraklardır. Kireçsiz kahverengi topraklar il çapında 157.684 hektarlık alanda yayılım göstermektedir. Kırmızı akdeniz topraklari: ABC horizonlu topraklardır. İlimizde toplam il çapında 47.077 hektarlık alanda yayılım göstermektedir. Kırmızı kahverengi akdeniz topraklari: $\mathrm{Bu}$ topraklar esas itibariyle Kırmızı Akdeniz ve Kahverengi Akdeniz topraklarının karışımıdır. Toplam yayılma alanı il çapında 133.381 hektarlık alandır. Bazaltik topraklar: Bu toprakların özellikleri aynı şartlar altında kireç taşı üzerinde teşekkül etmiş olan kahverengi ve kırmızikahverengi topraklara oldukça benzerlik gösterir. Bazaltik topraklar il çapında 50.062 hektarlık alanda yayılım göstermektedir. Kestane rengi topraklar: ABC veya (B) profiline sahip, kalsifikasyon sonucu oluşmuş zonal bir topraktır. Kestane rengi topraklar ise il çapında toplam 2566 hektarlık alanda yayılım göstermektedir.

Bölgenin jeolojisi şist, serpantin, kireç taşı, kumtaşı, marn, konglomera, alüvyal ve kolüvyal depozitler içeren metamorfik ve sediment kayalarından oluşmuştur.
Toprakların tekstür yapıları killi, siltli-killi ve kumlusiltli arasında değişir. KSÜ Avşar yerleşkesi toprak tekstürü haritası Şekil 2'de gösterilmiştir.

\section{İklim}

Kahramanmaraş üç ayrı coğrafi bölgenin (Akdeniz Bölgesi, Doğu Anadolu Bölgesi, Güneydoğu Anadolu Bölgesi) birbirine en çok yaklaştığı alanda yer alır. Coğrafi konumu ve diğer faktörlerin de etkisi ile üç farklı iklim tipi arasında Bozulmuş Akdeniz İklimi'ne daha yakın bir iklim özelliği gösterir. İlin büyük bir bölümünde Akdeniz iklimi görülmektedir. Kuzeye doğru gidildikçe ve yükselti arttıkça iklim değişmeye başlar. Yıllık ortalama sıcaklıklar güneyden kuzeye doğru yüksekliğin artmasına bağlı olarak azalmakta ve karasallık ön plana çıkmaktadır (Karabulut ve Cosun, 2009).

Özellikle Göksun, Afşin, Elbistan gibi ilçeler Doğu Anadolu iklim özelliklerine, Kahramanmaraş merkez ve yakın çevreleri hem Akdeniz hem de Güney Doğu Anadolu Bölgesinin iklim özelliklerine sahiptir. Bu nedenle yazları sıcak ve kurak, kışları ise ılıman ve yağışlı özellik gösterir. 1929 ile 2016 yılları arasındaki ölçüm periyodu verilerine göre (Şekil 3), uzun ylllar aylık sıcaklık ortalaması $16,9{ }^{\circ} \mathrm{C}$, uzun yıllar yıllık yağış ortalaması $727,7 \mathrm{~kg} / \mathrm{m}^{2}$, en düşük sıcaklık değeri Şubat ayında $-9,6{ }^{\circ} \mathrm{C}$, en yüksek sicaklık değeri ise $47,5{ }^{\circ} \mathrm{C}$ olarak Ağustos ayında ölçülmüştür.

Merkez ilçe deniz seviyesinden 568 metre yükseklikte olup, il genelinin arazi yüksekliği 350 metreden başlayarak 3.075 metreye kadar yükselir. Denize olan uzaklığ (İskenderun Körfezi) takriben 140 km'dir (Anonim, 2011).

\section{MATERYAL ve YÖNTEM}

$\mathrm{Bu}$ araştırma, arazi ve laboratuvar olmak üzere iki aşamadan oluşmaktadır. Arazi çalışmaları Nisan 2016 Haziran 2017 yılları arasında gerçekleştirilmiştir. Bitkilerin çiçeklenme ve meyvelenme süreleri göz önünde bulundurularak çalışma alanından bitkiler toplanmıştır. Yerleşkede toplanıp laboratuvara getirilen bitki örnekleri standart herbaryum tekniklerine uygun olarak kurutulmuş ve herbaryum örneği haline getirilmiştir.

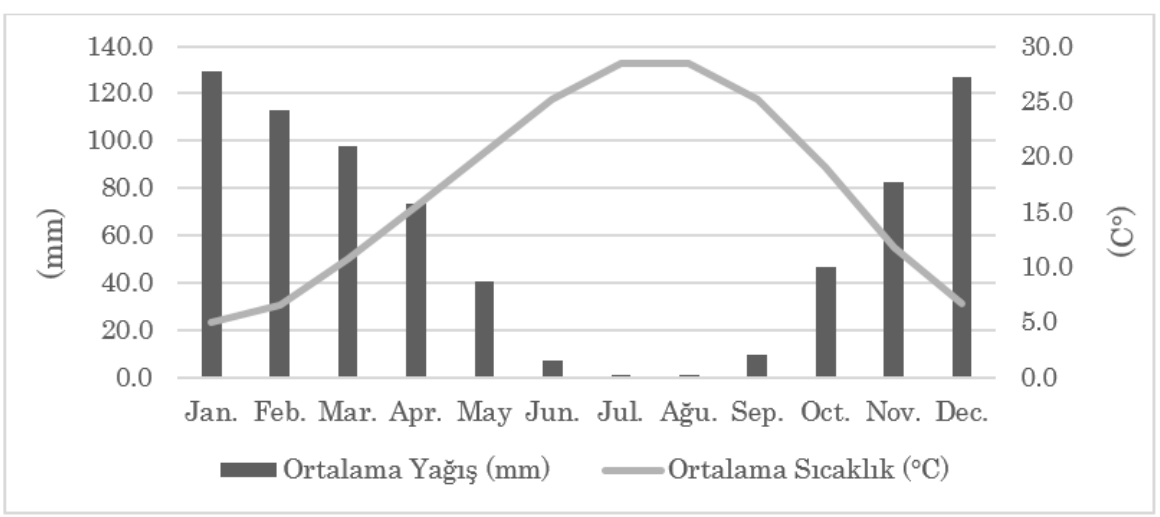

Şekil 3. Uzun yıllar ortalama yağış ve sıcaklık grafiği (1929-2016) 
Bitki örneklerinin teşhisinde 2'si ek cilt olmak üzere 11 ciltlik "Flora of Turkey and The East Aegean Islands" adlı temel eser kullanılmıştır (Davis, 1965-85; Davis ve ark., 1988; Güner ve ark., 2000). Aynı zamanda resimli bitki atlaslarından (Bonnier, 191234; Polunin, 1981; Godet, 1991; Wright, 1992; Phillips, 1994; Lanzara ve Pizzetti, 1997, Foulis ve Meynert, 1999; Fitter ve ark., 2000), çeşitli bitki teşhis kılavuzlarından (Harrington, 1957; Davis ve Cullen, 1989; Yaltırık ve Efe, 1996; Baytop, 1998; Tekin, 2007, 2011) faydalanılmıştır.

Teşhis anahtarlarında kullanılan terimlerin Türkçe karşılıkları için "Botanik Kılavuzu (İngilizce-Türkçe)" kullanılmıştır (Baytop, 1998). Bitkilerin Türkçe adları için ise "Türkçe Bitki Adları Sözlüğü"nden faydalanılmıştır (Baytop, 1994).

Araştırma alanına ait sistematik liste oluşturulurken; Spermatophyta bölümünün Gymnospermae alt bölümüne ait taksonlar Davis'e (1965-85) göre ve Angiospermae alt bölümüne ait sinıf, takım ve familyalar ise Cronquist (1988) yöntemine göre listelenmiştir.

Cronquist, sistematikte en yeni morfolojik, anotomik, sitolojik, palinolojik, biyokimyasal ve paleobotaniksel bulgulara yer vermiştir. Cronquist (1988) tüm Angiospermleri Magnoliatae (Dicotyledoneae) ve
Liliatae (Monocotyledoneae) şeklinde iki sinıfa ayırmıştır. Bunlardan Magnoliatae sınıfı 6 altsınıfa, Liliatae sınıfı ise 5 altsinıfa ayrılmaktadır.

Sistematik listede taksonlar, taksonomik kategorileri de yazılarak listelenmiştir. Ayrıca taksonun bulunduğu lokalite, habitat, yükselti, toplama tarihi, bilinenlerin fitocoğrafik bölgeleri, toplayıcı ve KASOF numarası (Kahramanmaraş Sütçü İmam Üniversitesi Orman Fakültesi Herbaryumu) belirtilmiştir. Ayrıca bitkilerin toplandiğ (Google Earth) göre oluşturulmuş olan KSÜ Avşar yerleşkesi karelaj sistemi kullanılarak eklenmiştir (Şekil 4). Sınıf, alt sınıf, takım, familya, tür ve türalı kategoriler listede kolaylık sağlanması amacıyla sıra ile numaralandırılmıştır. Endemik bitkilerin tehlike kategorilerinin belirlenmesinde Türkiye Bitkileri Kırmızı Kitabı'ndan ve IUCN verilerinden yararlanılmıştır (Ekim ve ark., 2000; IUCN, 2001).

\section{BULGULAR}

\section{Saptanan Taksonlarin Sayısal ve Oransal Olarak Değerlendirilmesi}

Araştırma alanında, Spermatophyta bölümüne ilişkin 65 familya ve 194 cinse ait toplam 279 tohumlu bitki taksonu saptanmıştır. Bu taksonların taksononomik birimlere dağ̣lımı aşağıda gösterilmiştir (Şekil 5).
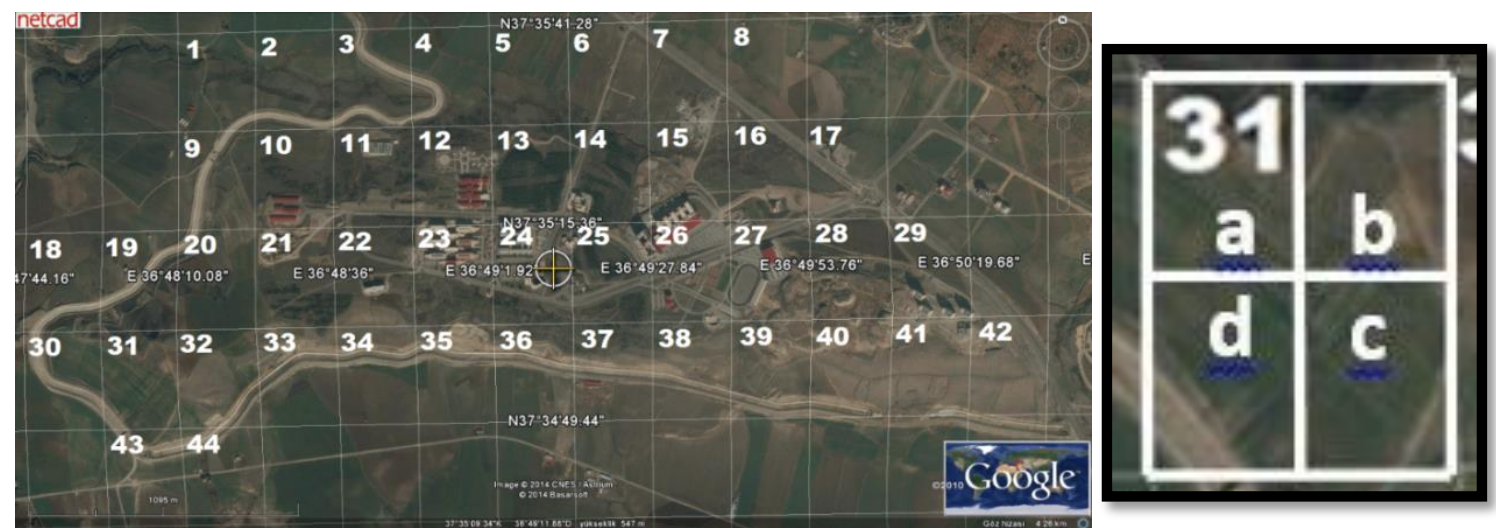

Şekil 4. KSÜ Avşar yerleşkesi enlem ve boylam derecelerine göre oluşturulmuş karelaj sistemi ve saat işleyişi yönünde harflendirilmiş tek bir karelaj

Angiospermae alt bölümünde yer alan 265 adet taksonun 237 adeti (\%89) Magnoliatae sinifina ve 28 adeti de (\%11) Liliatae sinıfina aittir. Her iki sinıfa ait taksonların altsınıf düzeyinde oransal dağılımları aşağıda verilmiştir (Şekil 6,7 ).

Çalışma alanında saptanan 279 taksonun 85 (\%30.46) adetinin fitocoğrafik bölgesi belirlenebilmiştir. $\mathrm{Bu}$ taksonlardan 10 adeti (\%3.58) Avrupa-Sibirya, 21 adeti (\%7.53) İran-Turan ve 54 adeti (\%19.35) Akdeniz elementidir (Çizelge 1, Şekil 8).

Yerleşke alanında saptanan 65 familyadan takson zenginliği açısından önde gelen familyalar ve bu familyalara ait taksonlarin sayısal ve oransal dağılımları çizelge 2 ve şekil 9'da verilmiştir. 


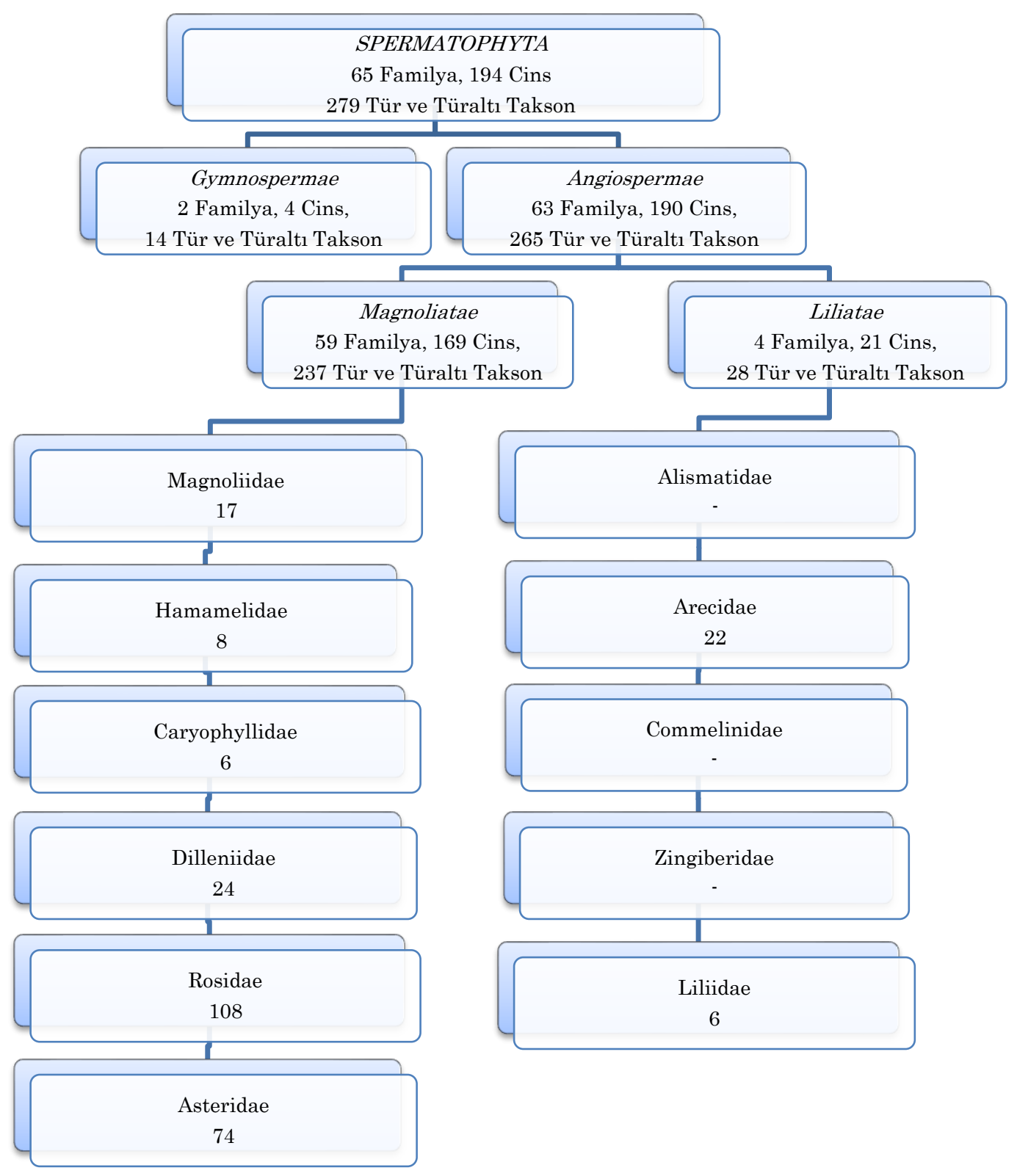

Şekil 5. Saptanan taksonların taksonomik birimlere dağılımı

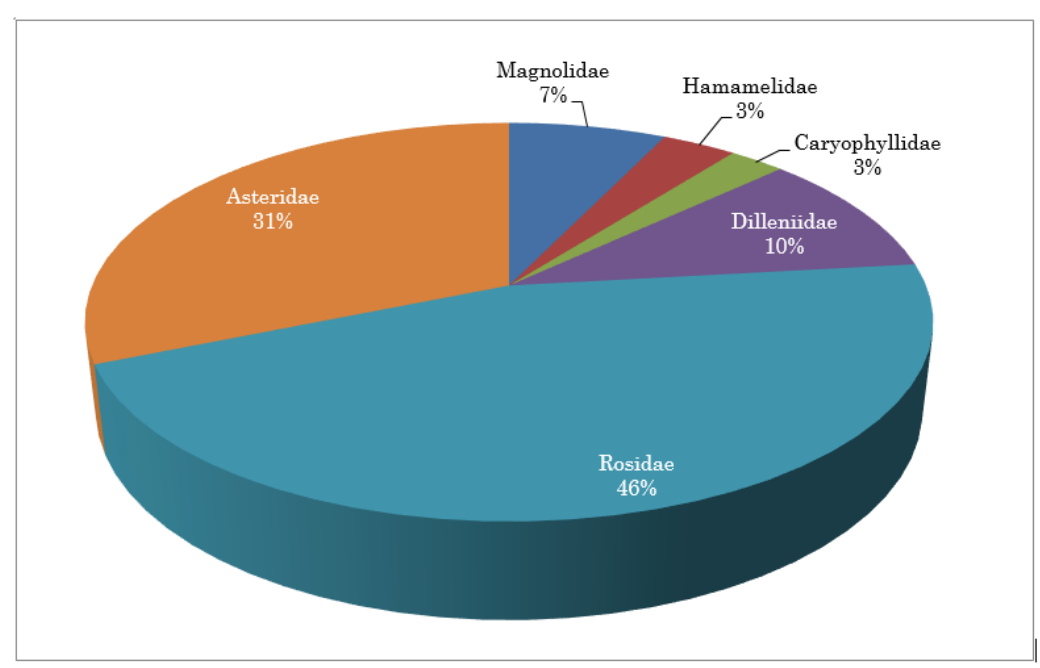

Şekil 6. Magnoliatae sınıfına ait taksonların altsınıf düzeyinde oransal dağılımı 


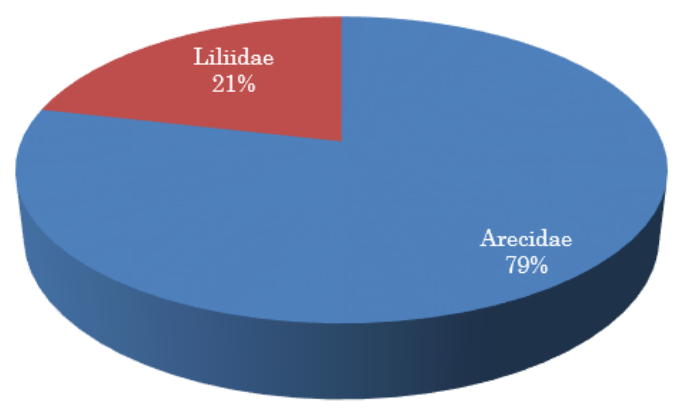

Şekil 7. Liliatae sınıfına ait taksonların altsınıf düzeyinde oransal dağılımı

Çizelge 1. Saptanan taksonların fitocoğrafik bölgelere göre sayısal ve oransal dağılımları

\begin{tabular}{|c|c|c|c|c|c|c|}
\hline \multirow[t]{2}{*}{ Fitocoğrafik Bölgeler } & \multirow{2}{*}{$\begin{array}{l}\text { Takson } \\
\text { Sayısı } \\
\text { (adet) }\end{array}$} & \multicolumn{2}{|l|}{ Oran (\%) } & \multirow{2}{*}{$\begin{array}{l}\text { Takson } \\
\text { Sayısı } \\
\text { (adet) }\end{array}$} & \multicolumn{2}{|l|}{ Oran (\%) } \\
\hline & & Yerleşke* & $\mathrm{FCBB}^{* *}$ & & Yerleşke* & $\mathrm{FCBB}^{* *}$ \\
\hline Euro-Siberian element & 9 & 3.23 & 10.59 & \multirow{2}{*}{10} & \multirow{2}{*}{3.58} & \multirow{2}{*}{11.76} \\
\hline Hyrcanian el. & 1 & 0.36 & 1.18 & & & \\
\hline Irano-Turanian element & 21 & 7.53 & 24.71 & 21 & 7.53 & 24.71 \\
\hline Mediterranean element & 36 & 12.90 & 42.35 & \multirow{4}{*}{54} & \multirow{4}{*}{19.35} & \multirow{4}{*}{63.53} \\
\hline Mediterranean (mt.) el. & 1 & 0.36 & 1,18 & & & \\
\hline East Mediterranean (mt.) el. & 2 & 0.72 & 2.35 & & & \\
\hline East Mediterranean el. & 15 & 5.38 & 17.65 & & & \\
\hline Ara Toplam & 85 & & & 85 & & \\
\hline Diğer & 194 & 69.53 & - & 194 & 69.53 & - \\
\hline Toplam & 279 & 100 & 100 & 279 & 100 & 100 \\
\hline
\end{tabular}

Yerleşke* : Araştırma alanında saptanan toplam takson adetine (279) göre oran

FCBB $^{* *}$ : Fitocoğrafik bölgeleri belirlenebilen toplam takson adetine (85) göre oran

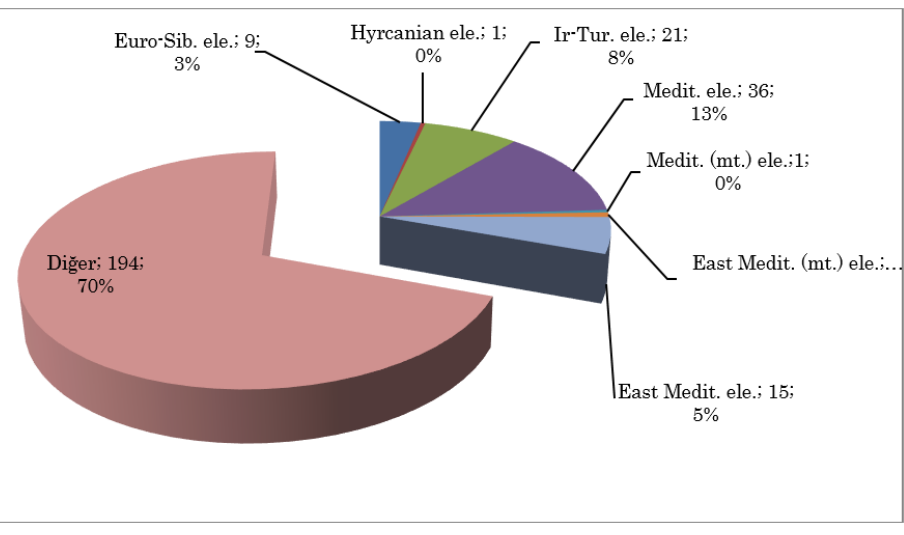

Şekil 8. Araştırma alanında saptanan taksonların fitocoğrafik bölgelere oransal dağılımı

Çizelge 2. Araştırma alanında saptanan taksonların familyalara göre sayısal ve oransal dağılımları

\begin{tabular}{ccc}
\hline Familya & Takson Sayıs (adet) & Oran (\%) \\
\hline Fabaceae & 54 & 19 \\
\hline Asteraceae & 29 & 10 \\
\hline Poaceae & 21 & 8 \\
\hline Rosaceae & 11 & 4 \\
\hline Apiaceae & 10 & 4 \\
\hline Brassicaceae & 10 & 4 \\
\hline Lamiaceae & 9 & 3 \\
\hline Ranunculaceae & 9 & 3 \\
\hline Ara Toplam & 153 & 55 \\
\hline Diğer & 126 & 100 \\
\hline Genel Toplam & 279 &
\end{tabular}




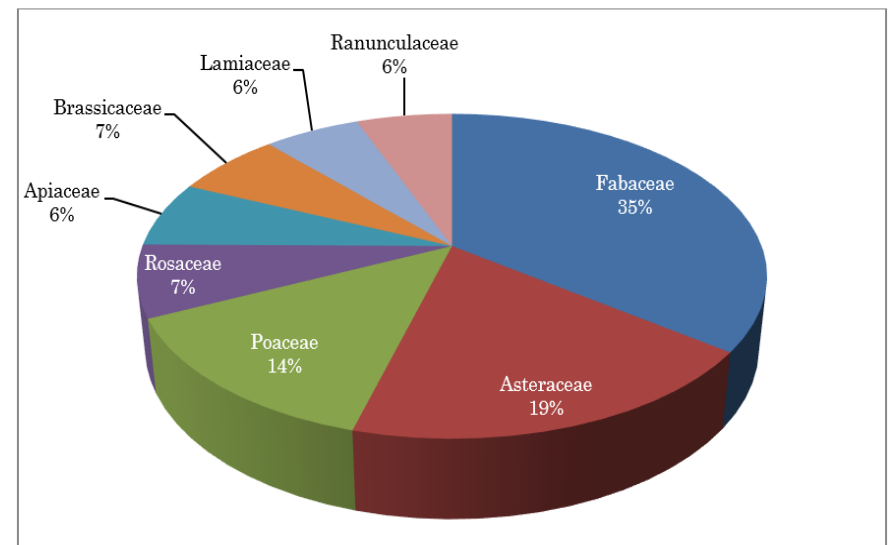

Şekil 9. Yerleşke alanında saptanan taksonların familyalara göre oransal dağılımları

Yerleşke alanından tespit edilen taksonlar içerisinden 145 takson (\%51.97) çok yıllık, 128 takson (\% 45.88) tek yıllık ve 6 takson (\% 2.15) ise iki yıllıktır (Şekil 10). Tespit edilen taksonlardan 198 takson (\% 70.97) otsu bitki, 44 takson (\% 15.77) ağaç, 37 takson (\% 13.26) ise çalı formundadır (Şekil 11).

Yerleşke alanından tespit edilen toplam 279 taksonun, \% 45.88'i “Therophyte" (128 takson), \%26.16's "Phanerophyte" (73 takson) hayat formuna sahip olup bunu sirasiyla; "Hemicryptophyte" (55 takson; \%19.71), "Cryptophyte" (15 takson; \%5.38) ve "Chamaephyte" (8 takson; \%2.87) hayat formları takip etmektedir (Şekil 12).

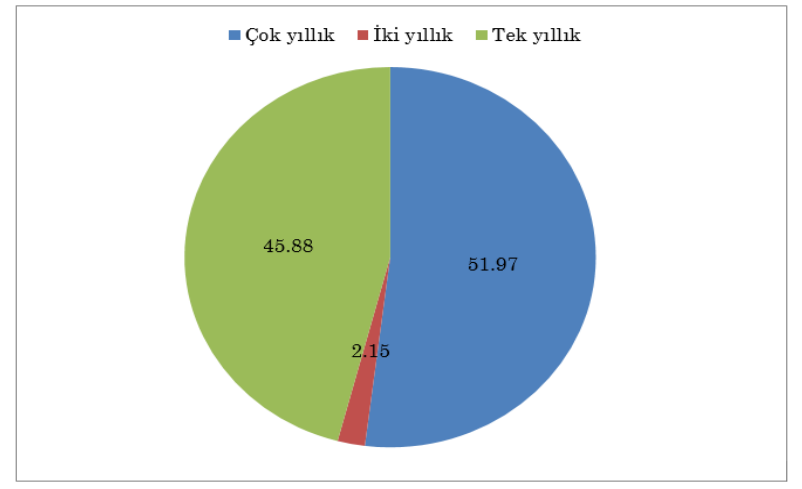

Şekil 10. Tespit edilen taksonların yaşam süreleri (\%)

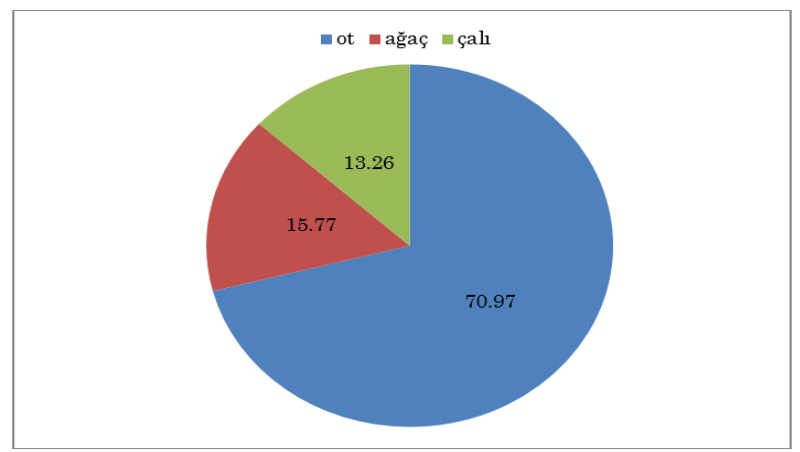

Şekil 11. Tespit edilen taksonların bitki tipleri (ağaç, çalı ve otsu bitki) (\%)

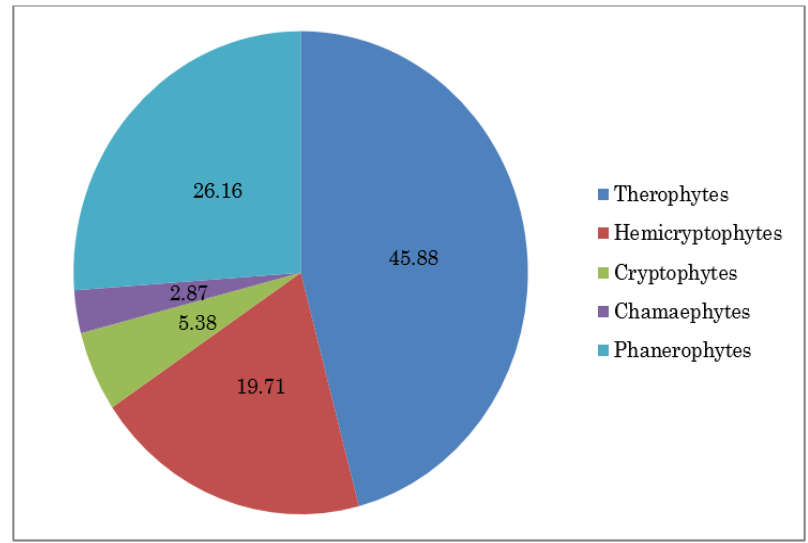

Şekil 12. Tespit edilen taksonların hayat formlarına dağılımları (\%)

\section{TARTIŞMA ve SONUÇ}

Avşar yerleşkesi tohumlu bitkilerini tespit etmek amacı ile 2016-2017 yılları arasında vejetasyon dönemlerinde gerçekleştirilen arazi çalışmaları sonucunda 399 bitki örneği toplanmıştır. Toplanan bitki örneklerinin teşhisleri sonucu; 65 familya ve 194 cinse ait 244 tür, 22 alttür ve 13 varyete olmak üzere toplamda 279 takson tespit edilmiştir. Bu taksonların tamamı Spermatophyta bölümüne aittir. Spermatophyta üyelerinden 14'ü Gymnospermae ve 265'i Angiospermae alt bölümüne dâhildir. Angiospermae'lerin 237'si Magnoliatae ve 28'i Liliatae sinıfında yer almaktadır. Yerleşke alanında toplam 2 (\%0.71) adet bitki taksonu endemiktir. Bu taksonların tehlike kategorileri Çizelge 3'de verilmiştir.

Çizelge 3. Alandaki endemik bitkiler ve tehlike kategorileri

\begin{tabular}{ll}
\hline Endemikler & IUCN Tehlike Kategorisi \\
\hline Papaver clavatum & LC \\
\hline Trigonella kotschyi & LC \\
\hline
\end{tabular}

Yerleşke alanında toplanan bitki taksonlarının familyalara dağılımı ve oranları Çizelge 4'de verilmiştir; En fazla takson sayısına sahip başlıca familyalar: Fabaceae 54 takson (19.35), Asteraceae 29 takson (\%10.39), Poaceae 21 takson (\%7.52), Rosaceae 11 takson (\%3.94), Apiaceae 10 takson (\%3.58), Brassicaceae 10 takson (\%3.58), ve diğerleri 144 takson (\%51.61)'dur.

Kahramanmaraş Sütçü İmam Üniversitesi yerleşke alanı, Davis'in kareleme sistemine göre C6 karesinde bulunmakta ve fitocoğrafik yönden İran-Turan ve Akdeniz fitocoğrafik bölgelerinin geçiş kuşağında yeralmaktadır. Yapılan çalışma sonucunda tespit edilen 279 taksonun, 54'ü Akdeniz bölgesi elementi, 21'i İran-Turan bölgesi elementi, 10’u Avrupa-Sibirya bölgesi elementi ve 194 adeti ise çok bölgeli ve bölgesi bilinmeyen taksonlardan oluşmaktadır. 
Yerleşke alanından tespit edilen taksonların fitocoğrafik bölge elementlerine göre dağılımı çizelge 5 'de verilmiştir. Yerleşke alanı Akdeniz bölgesinde bulunduğundan Akdeniz elementlerinin sayısının yüksek olması beklenen bir sonuçtur. Çok bölgeli ve bölgesi bilinmeyen elementlerin sayısının fazla olması ise, ülkemizin bu üç fitocoğrafik bölgenin kesişme noktasında bulunması ile açıklanabilir. Aynı zamanda Akdeniz ile İran-Turan fitocoğrafik bölgeleri Kahramanmaraş ili sınırları içerisinde de kesişmektedir.

Yerleşke karelaj sistemine göre en fazla takson (12b) (14d) ve (12c) karelerinden toplanmıştır (Çizelge 7). Endemik olduğu tespit edilen Papaver clavatum Boiss. et Hausskn. ex Boiss. yerleşke karelaj sistemine göre (12c) ve (22d) karelerinden tespit edilmiştir. Diğer endemik takson Trigonella kotschyi Fenzl ise (12c), (14d), (12a) karelerinde yayılış göstermektedir.

\section{ÖNERİLER}

$\mathrm{Bu}$ araştırma kapsamında belirlenen bitki türü zenginliğinin, yerleşkede yapılacak tüm çalışmaları koruma-sürdürebilme adına yönlendirebilmesi sağlanmalıdır. Bu kapsamda, yapılacak bitkilendirme çalışmalarında doğal türlerden yararlanma yoluna da gidilmeli, yabancı yurtlu türlerin kullanımı sinırlandırılmalıdır. Araştırılan bitki türleri içerisinden peyzaj amacina uygun olanlar ileride yapılacak bitkilendirme çalışmaları için çoğaltılarak kullanımları sağlanmalıdır.

Çizelge 4. Yerleşke alanında en çok takson içeren familyaların diğer üniversitelerde yapılan çalışmalarla karşılaştırılması

\begin{tabular}{|c|c|c|c|c|c|c|}
\hline & \multicolumn{5}{|c|}{ Oran (\%) } & \multirow[b]{2}{*}{ Toplam } \\
\hline & Fabaceae & Asteraceae & Poaceae & Rosaceae & Lamiaceae & \\
\hline Sütçü İmam Üniv. & 19.4 & 10.4 & 7.5 & 3.9 & 3.2 & 41.2 \\
\hline Akdeniz Üniv. (Ünal ve Gökçeoğlu, 2003) & 10.60 & 15.23 & - & 6.62 & 6.62 & 32.45 \\
\hline Anadolu Üniv. (Türe ve Böcük, 2001) & 7.9 & 9.9 & - & - & 6.00 & 17.8 \\
\hline Balıkesir Üniv. (Sanön ve Özen, 2001) & 6.7 & 9.7 & 8.99 & 4.1 & 6.4 & 29.49 \\
\hline Çukurova Üniv. (Bulut ve Düzenli, 2009) & 10 & 14 & 12 & - & 6 & 36 \\
\hline Dumlupınar Üniv. (Tatlı ve ark., 2002) & 10.7 & 14.4 & 8.4 & - & 6.5 & 33.5 \\
\hline Gaziantep Üniv. (Özuslu, 2004) & 12 & 11.3 & 6.8 & 7.3 & 5.6 & 37.4 \\
\hline Kafkas Üniv. (Yılmaz, 2012) & 8.8 & 17.7 & - & 5.1 & 8.5 & 31.6 \\
\hline Mustafa Kemal Üniv. (Altay, 2012) & 11.6 & 6.2 & - & 6.9 & - & 24.7 \\
\hline Ordu Üniv. (Deveci ve ark., 2012) & 12.11 & 11.66 & 15.25 & - & 5.83 & 39.02 \\
\hline Süleyman Demirel Üniv. (Fakir ve ark., 2009) & 14.91 & 13.04 & 9.32 & - & - & 37.27 \\
\hline Başkent Üniv. (Töre ve Erik, 2012) & 11.5 & 13.6 & - & - & 8.6 & 25.1 \\
\hline Kırıkkale Üniv. (Nugay ve ark., 2007) & 12.66 & 12.93 & 7.81 & - & 5.12 & 38.52 \\
\hline
\end{tabular}

Çizelge 5. Yerleşke alanındaki fitocoğrafik bölge elementlerinin diğer üniversiteler de yapılan çalışmalarla karşılaştırılması

\begin{tabular}{lllll}
\hline & \multicolumn{3}{c}{ Oran (\%) } \\
\cline { 2 - 4 } & Akdeniz & İran-Turan & Avrupa-Sibirya & Bilinmeyen \\
\hline Sütçü İmam Üniv. & $\mathbf{1 9 . 3 5}$ & 7.53 & 3.58 & 69.53 \\
\hline Akdeniz Üniv. (Ünal ve Gökçeoğlu, 2003) & $\mathbf{4 0 . 9 3}$ & 2.65 & 1.55 & 54.53 \\
\hline Anadolu Üniv. (Türe ve Böcük, 2001) & 3,3 & 7,7 & $\mathbf{8 , 8}$ & 80.2 \\
\hline Balıkesir Üniv. (Sanön ve Özen, 2001) & $\mathbf{1 9 , 9}$ & 3,0 & 8,2 & 68.9 \\
\hline Çukurova Üniv. (Bulut ve Düzenli, 2009) & $\mathbf{4 1}$ & 6 & 4 & 52 \\
\hline Dumlupinar Üniv. (Tatlı ve ark., 2002) & $\mathbf{7}$ & $\mathbf{1 6}$ & 4 & 73 \\
\hline Gaziantep Üniv. (Özuslu, 2004) & 16 & $\mathbf{2 2}$ & 0,5 & 61.5 \\
\hline Kafkas Üniv. (Yulmaz, 2012) & 1.7 & $\mathbf{2 1 . 8}$ & 19.1 & 57.3 \\
\hline Niğgde Üniv. (Başköse ve ark., 2012) & 6.4 & $\mathbf{2 1 . 0}$ & 6.2 & 66.4 \\
\hline Ordu Üniv. (Deveci ve ark., 2012) & 2.42 & 0.45 & $\mathbf{2 5 . 1 1}$ & 72 \\
\hline Ondokuz Mayss Üniv. (Özen ve Kılınç, 1996) & 16.44 & - & $\mathbf{2 0 . 5 5}$ & 63.01 \\
\hline Süleyman Demirel Üniv. (Fakir ve ark., 2009) & $\mathbf{1 8 . 6 3}$ & $\mathbf{1 5 . 5 3}$ & 3.73 & 42.24 \\
\hline Başkent Üniv. (Töre ve Erik, 2012) & 5.2 & $\mathbf{3 1 . 2}$ & 3.9 & 59.7 \\
\hline Kirıkale Üniv. (Nugay ve ark., 2007) & 7.3 & $\mathbf{2 6 . 9 7}$ & 2.53 & 63.2 \\
\hline
\end{tabular}


Çizelge 7. Yerleşke alanında oluşturulan karelaj sistemine göre takson sayılarının dağılımı

\begin{tabular}{|c|c|c|c|}
\hline Toplanan Karelaj & Toplam Takson Sayısı & Toplanan Karelaj & Toplam Takson Sayısı \\
\hline $11 a$ & 19 & $23 b$ & 31 \\
\hline $11 \mathrm{~b}$ & 30 & $23 c$ & 30 \\
\hline $12 \mathrm{a}$ & 14 & $23 d$ & 12 \\
\hline $12 \mathrm{~b}$ & 44 & $24 a$ & 26 \\
\hline $12 \mathrm{c}$ & 36 & $24 \mathrm{~b}$ & 6 \\
\hline $12 \mathrm{~d}$ & 7 & $24 \mathrm{c}$ & 2 \\
\hline $13 a$ & 4 & $24 d$ & 1 \\
\hline $13 b$ & 1 & $25 a$ & 3 \\
\hline $13 c$ & 1 & $25 b$ & 2 \\
\hline $13 d$ & 6 & $26 a$ & 4 \\
\hline $14 a$ & 14 & $26 c$ & 2 \\
\hline $14 \mathrm{~d}$ & 40 & $26 \mathrm{~d}$ & 4 \\
\hline $22 b$ & 16 & $27 \mathrm{~b}$ & 1 \\
\hline $22 \mathrm{c}$ & 18 & $27 \mathrm{c}$ & 1 \\
\hline $22 d$ & 8 & $28 a$ & 2 \\
\hline $23 a$ & 15 & & \\
\hline
\end{tabular}

Çizelge 6. Yerleşke alanında bulunan egzotik türler

\begin{tabular}{|c|c|c|}
\hline Yaşam Formu & Familyalar & Taksonlar \\
\hline \multicolumn{3}{|l|}{ Ağaçlar } \\
\hline & Pinaceae & Picea abies \\
\hline & Cupressaceae & $\begin{array}{l}\text { Cupressus arizonica, Cupressus macrocarpa, Juniperus } \\
\text { chinensis Platycladus orientalis, Thuja occidentalis }\end{array}$ \\
\hline & Aceraceae & Acer negundo, Acer buergerianum, Acer pseudoplatanus, \\
\hline & Arecaceae & Washingtonia robusta \\
\hline & Betulaceae & Betula pendula \\
\hline & Bignoniaceae & Catalpa bignonoides \\
\hline & Fabaceae & $\begin{array}{l}\text { Acacia dealbata, Albizzia julibrissin, Robinia hispida, Robinia } \\
\text { pseudoacacia }\end{array}$ \\
\hline & Magnoliaceae & Magnolia grandiflora \\
\hline & Meliaceae & Melia azedarach \\
\hline & Moraceae & Morus alba, Morus rubra \\
\hline & Myrtaceae & Eucalyptus camaldulensis \\
\hline & Nyctaginaceae & Bougainvillea spectabilis \\
\hline & Rhamnaceae & Rhamnus cathartica \\
\hline & Rosaceae & Crataegus crus-galli \\
\hline & Salicaceae & Salix babylonica \\
\hline & Sapindaceae & Koelreuteria paniculata \\
\hline & Scrophulariaceae & Paulownia tomentosa \\
\hline \multicolumn{3}{|c|}{ Çalılar ve Liyanlar } \\
\hline & Asteraceae & Santolina chamaecyparissus \\
\hline & Berberidaceae & Berberis thunbergii cv "Atropurpurea" \\
\hline & Bignoniaceae & Campsis radicans \\
\hline & Caprifoliaceae & Viburnum opulus, Viburnum tinus \\
\hline & Cornaceae & Cornus kousa \\
\hline & Fabaceae & Wisteria sinensis \\
\hline & Hydrangeaceae & Hydrangea macrophylla \\
\hline & Lamiaceae & $\begin{array}{l}\text { Lavandula stoechas subsp. stoechas, Lavandula angustifolia } \\
\text { subsp. angustifolia, Teucrium fruticans }\end{array}$ \\
\hline & Oleaceae & $\begin{array}{l}\text { Forsythia } x \text { intermedia, Ligustrum japonicum, Syringa } \\
\text { vulgaris, Fraxinus americana }\end{array}$ \\
\hline & Onagraceae & Gaura lindheimeri \\
\hline & Pittosporaceae & Pittosporum tobira \\
\hline & Rosaceae & Cotoneaster horizontalis, Cotoneaster franchetii \\
\hline & Verbenaceae & Lantana camara \\
\hline \multicolumn{3}{|l|}{ Otsu Taksonlar } \\
\hline & Liliaceae & Yucca gloriosa \\
\hline & Poaceae & Cortaderia selloana \\
\hline
\end{tabular}


Bitkiler öz kaynaklarımızdır. Ancak çoğunlukla yerleşke bitkisel tasarımlarında egzotik türlere ağırlık verilmekte ve milli servetimiz yersiz bir şekilde diğer ülkelere aktarılmaktadır. Ancak bu gibi çalışmalarla egzotik türlerin yerine doğal türlerimizle yapılacak planlamaları getirmemiz mümkün olacaktır.

Yerleşkede tespiti yapılan bitki taksonlarından bazılarının tohumdan veya çelikten üretimleri denenmeli mevcut sera sistemlerinde çoğaltma faaliyetleri gerçekleştirilmelidir. Bu türlerden amaca uygun olanlar yerleşke peyzaj planlarına dâhil edilmelidir. Özellikle çalı formundaki Cercis siliquastrum, Ceratonia siliqua, Laurus nobilis, Arbutus andrachne, Arbutus unedo, Myrtus communis, Punica granatum, Tamarix tetragyna, Spartium junceum ve Pyracantha coccinea gibi Akdeniz kökenli bitkiler üretim ve çoğaltmaya öncelikli olarak konu edilmelidir. Ayrıca, Consolida axilliflora, Adonis flammea, Linum nodiflorum, Linum pubescens, Haplophyllum buxbaumii, Vaccaria hispanica gibi otsu türler de kitlesel olarak çoğaltılarak renkleri sebebiyle koloni şeklinde kullanımları önerilmektedir. Buna ek olarak, Capparis spinosa, Malvella sherardiana Convolvulus dorycnium subsp. oxysepalus ve Trifolium tomentosum gibi türlerde yer örtücü olarak değerlendirilebilir.

Varlığı yerleşkemizde tespit edilen endemik ve nadir bitkiler yerleşke içerisinde gerçekleştirilecek peyzaj planlamalarında kullanılmalıdır. Böylece hem doğal vejetasyonun devamlılığının sağlanmasında hem de nesilleri tehdit altında olan bu bitkilerin in-situ ve exsitu korunmasında fayda sağlayacaktır. Endemik olduğu tespit edilen Papaver clavatum Boiss. et Hausskn. ex Boiss. ve Trigonella kotschyi Fenzl'nin yayılış gösterdikleri karelajlarda in-situ korunması yanında diğer karelajlara da uygulamaları yapılmalıdır. $\mathrm{Bu}$ yolla yerleşke alanına yapılacak müdahalelerde bu türlerin alandan uzaklaşmasına engel olunabilecektir. Uygulamalarda endemik türlerin yayılış gösterdiği özellikle (12c) karesine ve ayrica (12a), (14d) ve (22d) karelerine hassasiyet gösterilmelidir.

Bilindiği üzere tehdit altında bulunan bitkiler günümüzde yoğun bir şekilde konu edilen küresel iklim değişikliğinden ilk etkilenecek bitki gruplarındandır. Bu tehdit hiç şüphesiz bu türlerin yok olmasına dahi neden olabilecektir. Bunun için bu bitkiler ile ilgili güncel bilgilerin koruma planlarına mutlaka aktarılması gerekmektedir.

\section{TEŞEKKÜR}

$\mathrm{Bu}$ çalışma, KSÜ Bilimsel Araştırma Projeleri Koordinasyon Birimi tarafından desteklenen 2016/3$71 \mathrm{M}$ kod no projenin bir bölümüdür ve Yüksek Lisans Tezidir.

\section{KAYNAKLAR}

Altay V 2012. Mustafa Kemal Üniversitesi Tayfur Ata Sökmen Kampüsü (Hatay)'nün Süs Bitkileri. Karadeniz Fen Bilimleri Dergisi, 2 (6): 11-26.

Anonim 1997. Kahramanmaraş İli Arazi Varlığ ve Toprak Yapısı Raporu. Köy Hizmetleri Genel Müdürlüğü, Ankara, $240 \mathrm{~s}$.

Anonim 2005. Kahramanmaraş Belediyesi 2005 Yılı Faaliyet Raporu ve İlin Tanıtım Kitabı. Kahramanmaraş, $180 \mathrm{~s}$.

Anonim 2011. Kahramanmaraş İli Çevre Durum Raporu. CED Hizmetleri ve Cevre İzinleri Sube Müdürlüğü, Kahramanmaraş, $125 \mathrm{~s}$.

Avcı M 2005. Çeşitlilik ve Endemizm Açısından Türkiyenin Bitki Örtüsü. İstanbul Üniversitesi Edebiyat Fakültesi Coğrafya Dergisi, 13: 27-55.

Basser HC 2000. Phytochemical Diversity in the Flora of Turkey. 2 $2^{\text {nd }}$ Balkan Botanical Congress, 14-18 May, İstanbul, 517-528 pp.

Başköse İ, Paksoy MY, Savran A 2012. Niğde Üniversitesi Kampüs Alanı ve Akkaya Baraj Gölü Cevresinin Florası. Biological Diversity and Conservation, 5(3): 82-97.

Baytop A 1998. İngilizce-Türkçe Botanik Kılavuzu. İstanbul Üniversitesi Basımevi ve Film Merkezi, Üniversite Yayın No: 4058, Eczacılık Fakültesi Yayın No: 70, İstanbul, $375 \mathrm{~s}$.

Baytop T 1994. Türkçe Bitki Adları Sözlüğü. Türk Tarih Kurumu Basımevi, Türk Dil Kurumu Yayınları: 578, Ankara, $508 \mathrm{~s}$.

Bulut A, Düzenli A 2009. Hama Tepe, Deli Halil Tepe ve Tüysüz Tepe Florasının Belirlenmesi. Çukurova Üniversitesi Fen Bilimleri Enstitüsü Dergisi, 20(1): 111-119.

Bonnier G 1912-1934. Flore Complete Illustree en Couleurs de France Suisse et Belgique. Vol I-XII, Neuchatel, Paris, Bruxelles.

Cronquist A 1988. The Evolution and Classification of Flowering Plants. Second Edition, The New York Botanical Garden, New York, 555 p.

Davis PH 1965-85. Flora of Turkey and the East Aegean Islands. Vol I-IX., Edinburgh University Press, Edinburgh.

Davis PH, Cullen J 1989. The Identification of Flowering Plant Families. Third Edition, Cambridge University Press, Cambridge, 144 p.

Davis PH, Mill RR, Tan K 1988. Flora of Turkey and the East Aegean Islands. Vol. X, Supplement, Edinburgh University Press, Edinburgh, 600 p.

Deveci M, Bayrak Özbucak T, Demirkol G 2012. Ordu Üniversitesi Kampüs Alanı Florasının Tespiti. Akademik Ziraat Dergisi, 1(2): 107-116.

Ekim T, Koyuncu M, Vural M, Duman H, Aytaç Z, Adıgüzel N 2000. Türkiye Bitkileri Kırmızı Kitabı. (Eğrelti ve Tohumlu Bitkiler), Van Yüzüncü Yıl Üniversitesi ve Tabiatı Koruma Derneği, Barışcan Ofset, Ankara. 
Ekim T 2009. Türkiye'nin Nadir Endemikleri. İş Bankası Kültür Yayınları, İstanbul, $537 \mathrm{~s}$.

Erik S, Tarıkahya B 2004. Türkiye Florası Üzerine, Kebikeç. 17, Alp Matbaası, Ankara, 139-163 s.

Fakir H, Babalık A, Karatepe Y 2009. Süleyman Demirel Üniversitesi Kampüsü'nün Doğal Bitki Türleri (Isparta-Türkiye). Süleyman Demirel Üniversitesi Fen Bilimleri Enstitüsü Dergisi, 13(1): 33-39.

Fitter R, Fitter A, Blamey M 2000. Parey Blumenbuch. Blütenpflanzen Deutschlands und Nordwesteuropas, 3. Auflage, Parey Buchverlag, Berlin, $356 \mathrm{p}$.

Foulis L, Meynert M 1999. Botanica. Köneman Verlaagsgesell Schaft mbH, Bonner Staße, 126, D50968 Cologne, 1020 p.

Godet JD 1991. Pflanzen Europas Kräuter und Stauden. Mosaik Verlag, München, 264 p.

Gündoğan R, Demirkıran A.R, Yılmaz K 1998. KSÜ Avşar Kampusu Toprak Etüt ve Haritalanması, KSÜ Araştırma Fonu Projesi, (Proje No: 1996/17), $145 \mathrm{~s}$.

Güner A, Özhatay N, Ekim T, Başer KHC 2000. Flora of Turkey and the East Aegean Islands. Vol. XI, Supplement - II, Edinburgh University Press, Edinburgh, $656 \mathrm{p}$.

Güner A, Aslan S, Ekim T, Vural M, Babaç MT, (edlr.) 2012. Türkiye Bitkileri Listesi (Damarlı Bitkiler). Nezahat Gökyiğit Botanik Bahçesi ve Flora Araştırmaları Derneği Yayını, İstanbul, $1290 \mathrm{~s}$.

Gürbüz M 2001. Kahramanmaraş Merkez İlçe'nin Beşeri ve İktisadi Coğrafyası. T.C Kahramanmaraş Valiliği. İl Kültür Müdürlüğü Yayınları, No: 2, 241 s.

Harrington HD 1957. How to Identify Plants. The Swallow Press Inc., Chicago, 214 p.

IUCN 2001. IUCN Red List Categories and Criteria Version 3.1. IUCN Species Survival Commission Gland, Switzerland and Cambridge, UK, 33 p.

Karabulut M, Cosun F 2009. Kahramanmaraş İlinde Yağışların Trend Analizi (Precipitation Trend Analyses in Kahramanmaraş). Coğrafi Bilimler Dergisi, 7(1): 65-83.

Lanzara P, Pizzetti M 1997. Simon \& Schuster's Guide to Trees. Simon \& Schuster Inc., New York, 300 p.

Nugay ÖZ, Duran A, Doğan B 2007. Kırıkkale Üniversitesi Kampüs Florası. Selçuk Üniversitesi Fen Fakültesi Fen Dergisi 2(30): 79-92.

Özen F, Kılınç M 1996. Samsun Ondokuz Mayıs Üniversitesi'ndeki Kurupelit Kampüs Alanı ve Çevresinin Florası II. Anadolu Ege Tarımsal Araştırma Enstitüsü Dergisi, 6(1): 121-131.

Özuslu E 2004. Gaziantep Üniversitesi Kampüs Florası. Çevre Koruma Dergisi, 14(53): 25-32.

Phillips R 1994. Grasses, Ferns, Mosses \& Lichens of Great Britain and Ireland. Second Edition, Macmillan Publishers Ltd., London. 192 p.
Polunin O 1981. The Concise Flowers of Europe. Oxford University Press, London. 320 p.

Sanön B, Özen F 2001. Balıkesir Üniversitesi Çağış Kampüsü ve Çevresinin Flora ve Vejetasyonu. Ot Sistematik Botanik Dergisi, 8(2): 47-67.

Tatlı A, Tel AZ, Emre S 2002. Dumlupınar Üniversitesi Merkez Kampüsü (Kütahya) Florası. Dumlupınar Üniversitesi Fen Bilimleri Dergisi, 10. Yıl Özel Sayısı: 1-16.

Tekin E 2007. Türkiye'nin En Güzel Yaban Çiçekleri II. Türkiye İş Bankası Kültür Yayınları, 1256, Cilt: 2, 1. Baskı, İstanbul, $456 \mathrm{~s}$.

Tekin E 2011. Türkiye'nin En Güzel Yaban Çiçekleri I. Türkiye İş Bankası Kültür Yayınları, Cilt: 1, 4. Baskı, İstanbul, $664 \mathrm{~s}$.

Töre D, Erik S, 2012. Başkent Üniversitesi Bağlıca Yerleşkesi (Ankara)'nin Florası. Hacettepe Journal of Biology and Chemistry, 40(3): 267-291.

Türe C, Böcük H 2001. Anadolu Üniversitesi Kampüsü Florası (Eskişehir-Türkiye). Anadolu Üniversitesi Bilim ve Teknoloji Dergisi, 2(1): 83-95.

Ünal O, Gökçeoğlu M 2003. Akdeniz Üniversitesi Kampüs Florası (Antalya-Türkiye). Akdeniz Üniversitesi Ziraat Fakültesi Dergisi, 16(2): 143154.

Wright M 1992. The Complete Handbook of Garden Plants. Fourth Impression, Michael Joseph Ltd., London. 544 p.

Yaltırık F, Efe A 1996. Otsu Bitkiler Sistematiği Ders Kitabı. İkinci Baskı, İÜ Basımevi ve Film Merkezi, Üniversite Yayın No: 3940, Orman Fakültesi Yayın No: 10, İstanbul, $518 \mathrm{~s}$

Yılmaz MN 2012. Kafkas Üniversitesi Kampüs Florası. Kafkas Üni. Fen Bil. Enst., Biyoloji ABD, Yüksek Lisans Tezi, 133 s

Ek.1 Sistematik Tohumlu Bitki Listesi

\section{SPERMATOPHYTA GYMNOSPERMAE 1. Pinaceae}

1. Abies cilicica (Ant. et Kotschy) Carr. subsp. cilicica (Ant. et Kotschy) Carr. : Toros göknarı

KSÜ İlahiyat F.-Alakart arası (23c), ağaçlık alan, 535 m, 18.05.2017, S.Yağmur 312, KASOF 500, East Medit. (mt.) el.

2. Picea abies (L.) H. Karst. : Avrupa ladini

KSÜ İlahiyat F.-Alakart arası (23c), ağaçlık alan, 535 m, 18.05.2017, S.Yağmur 337, KASOF 501, Egzotik.

3. Cedrus libani A.Rich var. libani : Katran ağac1

KSÜ İlahiyat F.-Alakart arası (23c), ağaçlık alan, 535 m, 18.05.2017, S.Yağmur 320, KASOF 502, Medit. (mt.) el.

4. Pinus nigra J. F. Arnold subsp. nigra var. caramanica (Loudon) Rehder : Karaçam

KSÜ Kafeterya üst yol (25b), ağaçlık alan, 531 m, 18.05.2017, S.Yağmur 339, KASOF 503

5. P. brutia Ten. var. brutia : Kızılçam

KSÜ Ziraat F.- Kafeterya arası (13d), ağaçlık alan, 518 m, 18.05.2017, S.Yağmur 338, KASOF 504, East Medit. el.

6. P. pinea L. : Fistık çamı

KSÜ İlahiyat F.-Alakart arası (23c), ağaçlık alan, 535 m, 18.05.2017, S.Yağmur 340, KASOF 505. 


\section{Cupressaceae}

7. Cupressus sempervirens L. var. horizontalis (Mill.) Loudon KSÜ Kafeterya altı (14d), ağaçlık alan, 515 m, 18.05.2017, S.Yağmur 323, KASOF 506.

8. . sempervirens L. var. pyramidalis (O.Targ.Tozz.) Nyman KSÜ Kafeterya altı (14d), ağaçlık alan, 515 m, 18.05.2017, S.Yağmur 324, KASOF 507.

9. C. arizonica Greene.

KSÜ Kafeterya altı (14d), ağaçlık alan, 515 m, 07.06.2017, S.Yağmur 380, KASOF 508, Egzotik.

10. C. macrocarpa Hartw.

KSÜ Rektörlük ön bahçesi (24c), ağaçlık alan, 536 m, 16.06.2017, S.Yağmur 405, KASOF 509, Egzotik.

11. Juniperus foetidissima Willd. : Kokar ardıç

KSÜ Rektörlük binası civarı (24a), peyzaj düzenlemeleri, $545 \mathrm{~m}$, 07.06.2017, S.Yağmur 403, KASOF 510.

12. J. chinensis L. : Cin ardıcı

KSÜ Rektörlük binası civarı (24a), ağaçlık alan, 545 m, 01.06.2017, S.Yağmur 358, KASOF 511, Egzotik.

13. Platycladus orientalis L. : Doğu Mazıs

KSÜ Kafeterya üst yol (25a), peyzaj düzenlemeleri, $528 \mathrm{~m}$, 18.05.2017, S.Yağmur 342, KASOF 512, Egzotik.

14. Thuja occidentalis L. : Batı Mazısı

KSÜ Rektörlük binası civarı (24a), peyzaj düzenlemeleri, $545 \mathrm{~m}$, 07.06.2017, S.Yağmur 404, KASOF 513, Egzotik.

\section{ANGIOSPERMAE \\ A. MAGNOLIOPSIDA \\ I. Magnoliidae \\ I.1. Magnoliales \\ 3. Magnoliaceae}

15. Magnolia grandiflora L. : Büyük Çiçekli Manolya

KSÜ Ziraat F. önü (12d), peyzaj düzenlemeleri, 522 m, 18.05.2017, S.Yağmur 332, KASOF 514, Egzotik.

\section{I.2. Laurales}

4. Lauraceae

16. Laurus nobilis L. : Akdeniz Defnes

KSÜ Ziraat F. arkası (12a), ağaçlık alan, 508 m, 18.05.2017, S.Yağmur 330, KASOF 515, Medit. el.

\section{I.3. Aristolochiales \\ 5. Aristolochiaceae}

\section{Aristolochia maurorum L. : Kargabardağı}

KSÜ İlahiyat F.-Alakart arası (23d), orman içi açıklık, 536 m, 19.04.2017, S.Yağmur 270, KASOF 516, Ir.-Tur. el.

\section{I.4. Ranunculales}

6. Ranunculaceae

18. Adonis annua L. : Kanavciotu

KSÜ İlahiyat F.-Alakart arası (23d), çayırlık alan, 533 m, 24.04.2015, S.Yağmur 280, KASOF 517, Medit. el.

19. A. flammea Jacq. : Cinlalesi

KSÜ Kafeterya altı (14d), açıklık alan, 525 m, 23.4.2016, S.Yağmur 101, KASOF 518.

\section{A. microcarpa Dc. : Çiçeğesor}

KSÜ Yabancı Diller F. civarı (22c), yol kenarı, 536 m, 20.4.2016, S.Yağmur 35, KASOF 519; KSÜ Ziraat F. arkası (12a), açıklık alan, 515 m, 26.4.2016, S.Yağmur 117, KASOF 520; KSÜ Ziraat F. arkası (12b), açıklık alan, 513 m, 28.4.2016, S.Yağmur 136, KASOF 521; KSÜ Ziraat F. Terasları civarı (11b), yol kenarı, 510 m, 1.5.2016, S.Yağmur 157, KASOF 522

21. Consolida axilliflora (Dc) Schrödinger : Salkım mahmuz

KSÜ Yabancı Diller F. civarı (22b), açıklık alan, 540 m, 11.5.2016, S.Yağmur 217, KASOF 523; KSÜ Spor sahası etrafı (26a), yol kenarı, 529 m, 24.04.2015, S.Yağmur 282, KASOF 524.

22. Nigella orientalis L. : Şark çörekotu
KSÜ Ziraat F. Terasları civarı (11a), açıklık alan, 505 m, 1.5.2016, S.Yağmur 194, KASOF 525; KSÜ Ziraat F. Terasları civarı (11a), açıklık alan, $510 \mathrm{~m}, 1.5 .2016$, S.Yağmur 197, KASOF 526; KSÜ Yabancı Diller F. civarı (22b), açıklık alan, 540 m, 11.5.2016, S.Yağmur 214, KASOF 527.

23. Ranunculus arvensis L. : Düğün çiçeği

KSÜ Ziraat F. arkası (12b), açıklık alan, 513 m, 28.4.2016, S.Yağmur 148, KASOF 528; KSÜ Ziraat F. Terasları civarı (11a), açıklık alan, 505 m, 1.5.2016, S.Yağmur 189, KASOF 529; KSÜ Yabancı Diller F. civarı (22b), açıklık alan, 538 m, 11.5.2016, S.Yağmur 206, KASOF 530 .

24. $\boldsymbol{R}$. ficaria L. subsp. ficariiformis Rouy et Fouc. : Arpacıksalebi KSÜ Orman F.-İ̈BF F. arası (23b), yol kenarı, 530 m, 23.3.2016, S.Yağmur 7, KASOF 531.

25. R. marginatus Dâ'urv. var. trachycarpus (Fisch. et Mey.) Azn. : Çirnıkotu

KSÜ Ziraat F. Terasları civarı (11a), açıklık alan, 505 m, 1.5.2016, S.Yağmur 185, KASOF 532.

26. $R$. polyanthemos L.

KSÜ Ziraat F. Terasları civarı (11a), açıklık alan, 505 m, 1.5.2016, S.Yağmur 192, KASOF 533.

\section{Berberidaceae}

27. Berberis thunbergii L. cv "Atropurpurea" : Mor yaprakl Karamuk

KSÜ Ziraat F.-Kafeterya arası (13d), peyzaj düzenlemeleri, $530 \mathrm{~m}$, 18.05.2017, S.Yağmur 317, KASOF 534, Egzotik.

28. Bongardia chrysogonum (L.) Spach. : Çatlakotu

KSÜ Ziraat F. arkası (13a), açıklık alan, 508 m, 24.04.2015 S.Yağmur 281, KASOF 535, Ir.-Tur. el.

I.5. Papaverales

8. Papaveraceae

29. Papaver clavatum Boiss. et Hausskn. ex Boiss. : Şıkşık

KSÜ Ziraat F. civarı (12c), yol kenarı, 528 m, 23.3.2016, S.Yağmur 6, KASOF 536; KSÜ İlahiyat F. arkası (22d), açıklık alan, 530 m, 12.04.2017, S.Yağmur 261, KASOF 537, Endemik, IUCN: LC.

30. $P$. rhoeas L. : Gelincik

KSÜ Ziraat F. arkası (12b), açıklık alan, 513 m, 28.4.2016, S.Yağmur 149, KASOF 538; KSÜ Ziraat F. Terasları civarı (11b), yol kenarı, 510 m, 1.5.2016, S.Yağmur 158, KASOF 539

31. $P$. syriacum Boiss. et Blanche : Kellinar

KSÜ Ziraat F. civarı (12c), açıklık alan, 521 m, 21.4.2016, S.Yağmur 56 , KASOF 540

\section{Hamamelidae \\ II.1. Hamamelidales \\ 9. Platanaceae}

32. Platanus orientalis L. : Doğu Çınar

KSÜ Ziraat F.-Kafeterya arası (13d), ağaçlık alan, 525 m 18.05.2017, S.Yağmur 341, KASOF 541.

\section{Hamamelidaceae}

33. Liquidambar orientalis Miller var. orientalis : Anadolu Sığla Ağacı

KSÜ Rektörlük binası civarı (24a), ağaçlık alan, Peyzaj amaçlı dikimle getirilmiş, 533 m, 18.05.2017, S.Yağmur 331, KASOF 542, Kültür, (Endemik, IUCN: VU).

\section{II.2. Urticales \\ 11. Moraceae}

34. Ficus carica L. subsp. rupestris (Hausskn.) Browicz. : İncir KSÜ Tıp F.-Güzel Sanatlar F. arası (26a), ağaçlık alan, 527 m, 18.05.2017, S.Yağmur 326, KASOF 543, Ir.-Tur. el.

35. Morus alba L. : Ak dut

KSÜ Ziraat F. civarı (12c), yol kenarı, 538 m, 20.4.2016, S.Yağmur 40, KASOF 544, Egzotik.

36. M. rubra L. : Mor dut 
KSÜ İlahiyat F.-Alakart arası (23d), peyzaj düzenlemeleri, $534 \mathrm{~m}$, 18.05.2017, S.Yağmur 334, KASOF 545, Egzotik.

$$
\begin{aligned}
& \text { II.3. Juglandales } \\
& \text { 12. Juglandaceae }
\end{aligned}
$$

37. Juglans regia L. : Yaygin Ceviz

KSÜ Kafeterya altı (14d), ağaçlık alan, 515 m, 18.05.2017, S.Yağmur 329, KASOF 546.

$$
\begin{aligned}
& \text { II.4. Fagales } \\
& \text { 13. Fagaceae }
\end{aligned}
$$

38. Quercus robur L. subsp. robur: Saplı meşe

KSÜ Ziraat F. civarı (12c), ağaçlık alan, 527 m, 18.05.2017, S.Yağmur 355, KASOF 547, Euro-Sib. el.

\section{Betulaceae}

39. Betula pendula Roth : Sarkık Dallı Hus

KSÜ Orman F. arkası (23b), açıklık alan, 533 m, 07.06.2017, S.Yağmur 384, KASOF 548, Egzotik.

$$
\begin{aligned}
& \text { III. Caryophyllidae } \\
& \text { III.1. Caryophyllales } \\
& \text { 15. Caryophyllaceae }
\end{aligned}
$$

40. Cerastium brachypetalum Pers. subsp. roeseri (Boiss. et Heldr.) Nyman : Boynuzotu

KSÜ Kafeterya altı (14d), açıklık alan, 525 m, 23.4.2016, S.Yağmur 106, KASOF 549.

41. Minuartia hybrida (Vill.) Schischk. subsp. turcica Mcneill : Ekin tistisı

KSÜ Kafeterya altı (14d), açıklık alan, 525 m, 23.4.2016, S.Yağmur 97, KASOF 550.

42. Silene aegyptiaca (L.) L. Fil. subsp. ruderalis Coode et Cullen : Kaba Ballica

KSÜ İlahiyat F. arkası (22d), açıklık alan, 530 m, 12.04.2017, S.Yağmur 260, KASOF 551.

43. Vaccaria hispanica (Mill.) Rauschert var. grandiflora (Fisch. ex Dc.) Cullen : Ekinebesi

KSÜ Ziraat F. Terasları civarı (11b), açıklık alan, 505 m, 1.5.2016, S.Yağmur 183, KASOF 552; KSÜ Orman F.-İ̈BF arası (23b), yol kenarı, 535 m, 8.6.2016, S.Yağmur 234, KASOF 553; KSÜ Ziraat F. civarı (12c), açıklık alan, 537 m, 21.4.2016, S.Yağmur 54, KASOF 554.

\section{III.2. Polygonales \\ 16. Polygonaceae}

44. Polygonum salicifolium Brouss. ex Willd. : Bibercik

KSÜ Ziraat F. Terasları civarı (11a), açıklık alan, 500 m, 1.5.2016, S.Yağmur 198, KASOF 555.

45. Rumex pulcher L. : Ekşilik

KSÜ Ziraat F. arkası (12b), açıklık alan, 513 m, 28.4.2016, S.Yağmur 140, KASOF 556.

\section{Dilleniidae \\ IV.1. Malvales \\ 17. Malvaceae}

46. Alcea striata (Dc.) Alef. subsp. rufescens (Boiss.) Cullen : Kaya hatmisi

KSÜ Kafeterya karşısı (13c), yol kenarı, 535 m, 1.6.2016, S.Yağmur 236, KASOF 557

47. Althaea hirsuta L. : Gülhatmi

KSÜ Ziraat F. Terasları civarı (11b), yol kenarı, 510 m, 1.5.2016, S.Yağmur 178, KASOF 558.

48. Malva sylvestris L.: Ebegümeci

KSÜ İlahiyat F.-Alakart arası (23c), orman içi açıklık, $526 \mathrm{~m}$, 01.06.2017, S.Yağmur 370, KASOF 559.

49. Malvella sherardiana (L.) Jaub. et Spach : Hubazi
KSÜ Ziraat F. arkası (12b), açıklık alan, 513 m, 28.4.2016, S.Yağmur 144, KASOF 560.

50. Hibiscus syriacus L. : Kerkede

KSÜ İlahiyat F.-Alakart arası (23c), açıklık alan, 528 m, 07.06.2017, S.Yağmur 394, KASOF 561.

IV.2. Violales

18. Tamaricaceae

51. Tamarix tetragyna Ehrenb. : Ova ilginı

KSÜ Ziraat F. arkası (12b), açıklık alan, 513 m, 28.4.2016, S.Yağmur 146, KASOF 562, Ir.-Tur. el.

IV.3. Salicales

19. Salicaceae

52. Salix babylonica L. : Salkım Söğü

KSÜ Ziraat F.-Kafeterya arası (13d), peyzaj düzenlemeleri, $530 \mathrm{~m}$, 18.05.2017, S.Yağmur 347, KASOF 563, Egzotik.

53. S. caprea L. : Keçi söğüdü

KSÜ Ziraat F. civarı (12c), peyzaj düzenlemeleri, 529 m, 18.05.2017, S.Yağmur 348, KASOF 564, Euro-Sib. el.

54. S. viminalis $\mathrm{L}$. : Sepetçi söğüdü

KSÜ Orman F. önü (12d), peyzaj düzenlemeleri, 527 m, 01.06.2017, S.Yağmur 360, KASOF 565, Euro-Sib. el.

\section{IV.4. Capparales \\ 20. Capparaceae}

55. Capparis spinosa L. var. spinosa : Kebere

KSÜ Ziraat F. arkası (13b), açıklık alan, 506 m, 18.05.2017, S.Yağmur 318, KASOF 566.

\section{Brassicaceae}

56. Capsella bursa-pastoris (L.) Medik. : Çobançantası

KSÜ Ziraat F. civarı (12c), açıklık alan, $520 \mathrm{~m}, 10.04 .2017$, S.Yağmur 250, KASOF 567.

57. Cardaria draba (L.) Desv subsp. chalepensis (L.) O.E. Schulz Diğnik

KSÜ Orman F.-İ̈BF arası (23b), açıklık alan, 563 m, 14.4.2016, S.Yağmur 8, KASOF 568; KSÜ Ziraat F. Terasları civarı (11a), açıklık alan, $500 \mathrm{~m}, 1.5 .2016$, S.Yağmur 200, KASOF 569; KSÜ İlahiyat F. arkası (22d), açıklık alan, $534 \mathrm{~m}, 12.04 .2017$, S.Yağmur 262, KASOF 570.

58. Clypeola aspera (Grauer) Turrill : Killı akçeotu

KSÜ Kafeterya altı (14a), yol kenarı, 514 m, 23.4.2016, S.Yağmur 68, KASOF 571, Ir.-Tur. el.

59. C. jonthlaspi L.

KSÜ Ziraat F. civarı (12c), açıklık alan, 520 m, 21.4.2016, S.Yağmur 48, KASOF 572; KSÜ Kafeterya altı (14d), açıklık alan, 525 m, 23.4.2016, S.Yağmur 98, KASOF 573.

60. Crambe orientalis L. var. orientalis: Akyumak

KSÜ Kafeterya üst yol (25a), açıklı alan, 528 m, 24.04.2015, S.Yağmur 287, KASOF 574; KSÜ Ziraat F. arkası (12b), açıklık alan, $485 \mathrm{~m}$, 28.4.2016, S.Yağmur 121, KASOF 575, Ir.-Tur. el. 61. C. tataria Sebeok var. tataria: Tatarlahanasi

KSÜ İlahiyat F. arkası (22c), açılklık alan, $531 \mathrm{~m}, 12.04 .2017$, S.Yağmur 254, KASOF 576; KSÜ Spor sahası etrafı (22c), açıklık alan, 539 m, 27.04.2017, S.Yağmur 274, KASOF 577, Ir.-Tur. el. 62. Eruca sativa Miller: Roka

KSÜ Ziraat F. Terasları civarı (11b), yol kenarı, 510 m, 1.5.2016, S.Yağmur 181, KASOF 578.

63. Neslia apiculata Fisch, Mey. et Ave-Lall. : Tophardal

KSÜ Kafeterya altı (14a), yol kenarı, $514 \mathrm{~m}, 23.4 .2016$, S.Yağmur 70, KASOF 579; KSÜ İlahiyat F.-Alakart arası (23d), orman içi açılklık, 536 m, 19.04.2017, S.Yağmur 267, KASOF 580.

64. Sinapis arvensis L. : Hardal

KSÜ Orman F.-̇̇̈BF arası (23b), açıklık alan, $562 \mathrm{~m}, 13.4 .2016$, S.Yağmur 9, KASOF 581; KSÜ Ziraat F. civarı (12c), açıklık alan, 537 m, 21.4.2016, S.Yağmur 55, KASOF 582; KSÜ Ziraat F. civar (12c), açıklık alan, 537 m, 21.4.2016, S.Yağmur 58, KASOF 583; 
KSÜ Kafeterya altı (14d), açıklık alan, 522 m, 23.4.2016, S.Yağmur 80, KASOF 584; KSÜ Ziraat F. arkası (12a), açıklık alan, $514 \mathrm{~m}$, 26.4.2016, S.Yağmur 112, KASOF 585; KSÜ Ziraat F. arkası (12b), açıklık alan, 513 m, 28.4.2016, S.Yağmur 130, KASOF 586; KSÜ Ziraat F. Terasları civarı (11b), yol kenarı, $510 \mathrm{~m}, 1.5 .2016$, S.Yağmur 166, KASOF 587; KSÜ İlahiyat F. arkası (22d), açıklık alan, 529 m, 12.04.2017, S.Yağmur 256, KASOF 588.

65. Thlaspi perfoliatum L. : Çobandağarcığ 1

KSÜ Kafeterya altı (14a), yol kenarı, 521 m, 23.4.2016, S.Yağmur 72, KASOF 589.

\section{IV.5. Ericales \\ 22. Ericaceae}

66. Arbutus andrachne L. : Sandal ağacı

KSÜ Ziraat F. arkası (12b), peyzaj düzenlemeleri, 509 m, 18.05.2017, S.Yağmur 315, KASOF 590.

67. Arbutus unedo L. : Kocayemiş

KSÜ Ziraat F. civarı (12c), peyzaj düzenlemeleri, 529 m, 18.05.2017, S.Yağmur 316, KASOF 591

\section{IV.6. Primulales \\ 23. Primulaceae}

68. Anagallis arvensis L. var. caerulea (L.) Gouan : Farekulağ KSÜ Kafeterya altı (14d), açıklık alan, 522 m, 23.4.2016, S.Yağmur 85, KASOF 592; KSÜ Yabancı Diller F. civarı (23a), açıklık alan, $540 \mathrm{~m}, 11.5 .2016$, S.Yağmur 220, KASOF 593

69. Androsace maxima L. : Tavukkursağ

KSÜ İlahiyat F.-Alakart arası (23c), orman içi açıklık, $532 \mathrm{~m}$, 01.06.2017, S.Yağmur 362, KASOF 594.

$$
\begin{gathered}
\text { V. Rosidae } \\
\text { V.1. Rosales } \\
\text { 24. Pittosporaceae }
\end{gathered}
$$

70. Pittosporum tobira (Thunb.) W.T.Aiton : Bodur Yıldız Çalısı KSÜ İlahiyat F.-Alakart arası (23c), açıklık alan, 528 m, 07.06.2017, S.Yağmur 400, KASOF 595, Egzotik.

\section{Hydrangeaceae}

71. Hydrangea macrophylla (Thunb.) Ser. : Ortanca

KSÜ Orman F.-İ̈BF arası (23b), peyzaj düzenlemeleri, $535 \mathrm{~m}$, 18.05.2017, S.Yağmur 311, KASOF 596, Egzotik.

$$
\text { 26. Crassulaceae }
$$

72. Sedum acre L. : Acı damkoruğu

KSÜ Orman F.-ï̈BF arası (23b), yol kenarı, 535 m, 8.6.2016, S.Yağmur 235, KASOF 597.

\section{Rosaceae}

73. Amygdalus communis L. : Badem

KSÜ İlahiyat F. arkası (22c), açıklık alan, 522 m, 07.06.2017, S.Yağmur 379, KASOF 598.

74. A. orientalis Miller : Payam

KSÜ İlahiyat F.-Alakart arası (23c), açıklık alan, 528 m, 07.06.2017, S.Yağmur 393, KASOF 599, Ir.-Tur. el.

75. Cotoneaster horizontalis Decne. : Dağ muşmulası

KSÜ Rektörlük binası civarı (24b), peyzaj düzenlemeleri, $531 \mathrm{~m}$, 18.05.2017, S.Yağmur 322, KASOF 600, Egzotik.

76. C. franchetii Bois

KSÜ Rektörlük binası civarı (24a), peyzaj düzenlemeleri, $545 \mathrm{~m}$, 01.06.2017, S.Yağmur 356, KASOF 601, Egzotik.

77. Malus domestica Borkh. : Elma

KSÜ İlahiyat F.-Alakart arası (23c), açıklık alan, 528 m, 07.06.2017, S.Yağmur 395, KASOF 602.

78. Prunus cerasifera Ehrh. : Erik
KSÜ Rektörlük binası civarı (24a), peyzaj düzenlemeleri, $545 \mathrm{~m}$, 07.06.2017, S.Yağmur 390, KASOF 603.

79. P. serrulata Lindl. 'Kanzan'

KSÜ İlahiyat F.-Alakart arası (23c), açıklık alan, 528 m, 07.06.2017, S.Yağmur 397, KASOF 604; KSÜ Rektörlük binası civarı (24a), peyzaj düzenlemeleri, $545 \mathrm{~m}, 07.06 .2017$, S.Yağmur 406, KASOF 605.

80. Pyracantha coccinea Roemer : Ateşdikeni

KSÜ Orman F.-İ̈BF arası (23b), peyzaj düzenlemeleri, $542 \mathrm{~m}$, 18.05.2017, S.Yağmur 343, KASOF 606.

81. Rubus sanctus Schreber : Böğürtlen

KSÜ Kafeterya altı (14d), yol kenarı, 519 m, 23.4.2016, S.Yağmur 75, KASOF 607.

82. Sanguisorba minor Scop. subsp. lasiocarpa (Boiss. et Hausskn.) Nordb. : Karagöndürme

KSÜ Kafeterya altı (14a), yol kenarı, 514 m, 23.4.2016, S.Yağmur 62, KASOF 608; KSÜ Ziraat F. civarı (12c), açıklık alan, $521 \mathrm{~m}$, 21.4.2016, S.Yağmur 43, KASOF 609.

83. C. crus-galli L. : Alıç

KSÜ Rektörlük binası civarı (24a), peyzaj düzenlemeleri, $545 \mathrm{~m}$ 07.06.2017, S.Yağmur 392, KASOF 610, Egzotik.

$$
\begin{aligned}
& \text { V.2. Fabales } \\
& \text { 28. Fabaceae }
\end{aligned}
$$

\section{Acacia delbata Link : Gümüşi akasya}

KSÜ Rektörlük binası civarı (24a), peyzaj düzenlemeleri, $545 \mathrm{~m}$, 18.05.2017, S.Yağmur 313, KASOF 611, Egzotik.

85. Albizzia julibrissin Durazz. : Gülibrişim

KSÜ Kafeterya altı (14d), peyzaj düzenlemeleri, 515 m, 18.05.2017, S.Yağmur 314, KASOF 612, Egzotik, Hyrcanian el.

86. Astragalus hamosus L. : Geven, Koçboynuzu

KSÜ Besyo arkası (27c), açıklık alan, 531 m, 17.04.2017, S.Yağmur 266, KASOF 613

\section{Calicotome villosa (Poir.) Link : Keçiboğan}

KSÜ Yabancı Diller F. civarı (22c), açıklık alan, 536 m, 19.4.2016, S.Yağmur 34, KASOF 614, Medit. el.

88. Cercis siliquastrum L. subsp. siliquastrum : Erguvan

KSÜ Ziraat F. civarı (12c), peyzaj düzenlemeleri, 519 m, 18.05.2017, S.Yağmur 321, KASOF 615.

89. Coronilla parviflora Willd. : Burçak

KSÜ Orman F.-İ̈BF arası (24a), açıklık alan, 530 m, 24.04.2015, S.Yağmur 284, KASOF 616, East Medit. el.

90. C. scorpioides (L.) Koch : Akrep burçağ

KSÜ Orman F.-İ̈BF arası (24a), açıklık alan, 530 m, 24.04.2015, S.Yağmur 285, KASOF 617.

91. Glycyrrhiza echinata L. : Pitrak meyan

KSÜ Ziraat F. arkası (13d), yol kenarı, 527 m, 24.04.2015, S.Yağmur 292, KASOF 618

92. Hippocrepis unisiliquosa L. subsp. unisiliquosa : Atnalı

KSÜ İlahiyat F.-Alakart arası (23c), orman içi açıklık, $530 \mathrm{~m}$, 24.04.2015, S.Yağmur 293, KASOF 619.

93. Hymenocarpus circinnatus (L.) Savi : Pulluot

KSÜ Orman F.-İ̈BF arası (23b), açıklık alan, $560 \mathrm{~m}, 13.4 .2016$, S.Yağmur 14, KASOF 620; KSÜ Kafeterya altı (14d), açıklık alan, $525 \mathrm{~m}, 23.4 .2016$, S.Yağmur 103, KASOF 621; KSÜ İlahiyat F. Alakart arası (23d), yol kenarı, 532 m, 24.04.2015, S.Yağmur 294, KASOF 622, Medit. el.

\section{Lathyrus annuus L. : Dağdırılcası}

KSÜ Orman F-İ̇BF arası (24a), açıklık alan, 537 m, 18.4.2016, S.Yağmur 17, KASOF 623; KSÜ Ziraat F. arkası (12b), açıklık alan, 513 m, 28.4.2016, S.Yağmur 124, KASOF 624, Medit. el.

95. L. argentatus L. var. biflorus Post

KSÜ Ziraat F. Terasları civarı (11a), açıklık alan, 505 m, 1.5.2016, S.Yağmur 190, KASOF 625; KSÜ Ziraat F. arkası. (12b), açıklı alan, $507 \mathrm{~m}, 24.04 .2015$, S.Yağmur 296, KASOF 626.

96. L. aphaca L. var. modestus P. H. Davis : Sarı burçak

KSÜ Kafeterya altı (14d), açıklık alan, 522 m, 23.4.2016, S.Yağmur 82, KASOF 627

East Medit. el.

97. L. cicera L. : Colban 
KSÜ Ilahiyat F.-Alakart arası (23d), orman içi açıklı, $536 \mathrm{~m}$, 19.04.2017, S.Yağmur 268, KASOF 628.

98. L. gorgoni Parl. var. gorgoni : İmirdik

KSÜ Orman F.- İİBF arası (24a), açıklık alan, $560 \mathrm{~m}, 13.4 .2016$, S.Yağmur 15, KASOF 629; KSÜ Kafeterya altı (14d), açıklık alan, 525 m, 23.4.2016, S.Yağmur 99, KASOF 630; KSÜ Ziraat F. arkası (12a), açıklık alan, $514 \mathrm{~m}, 26.4 .2016$, S.Yağmur 114, KASOF 631; KSÜ Ziraat F. arkası (12b), açıklık alan, 513 m, 28.4.2016, S.Yağmur 137, KASOF 632; KSÜ Ziraat F. Terasları civarı (11b), yol kenarı, 510 m, 1.5.2016, S.Yağmur 169, KASOF 633, East Medit. el.

99. L. sativus $\mathrm{L}$.

KSÜ Ziraat F. Terasları civarı (11a), açıklık alan, 505 m, 1.5.2016, S.Yağmur 186, KASOF 634; KSÜ Ziraat F. arkası (12b), açıklık alan, 513 m, 28.4.2016, S.Yağmur 127, KASOF 635; KSÜ İlahiyat F.-Alakart arası (23d), orman içi açıklık, $532 \mathrm{~m}, 24.04 .2015$, S.Yağmur 297, KASOF 636.

100. Medicago blancheana Boiss. var. blancheana: Tarla yoncası

KSÜ Ziraat F. Terasları civarı (11b), yol kenarı, $510 \mathrm{~m}$, 1.5.2016, S.Yağmur 160, KASOF 637

101. M. lupulina L. : Bitçikotu

KSÜ Orman F.- İİBF F. arası (23b), açıklık alan, 537 m, 19.4.2016, S.Yağmur 28, KASOF 638.

102. M. minima (L.) Bart. var. minima: Gurnik

KSÜ Kafeterya altı (14d), açıklık alan, 525 m, 23.4.2016, S.Yağmur 91, KASOF 639; KSÜ Ziraat F. arkası (12b), açıklık alan, 513 m, 28.4.2016, S.Yağmur 139 KASOF 640; KSÜ Ziraat F. Terasları civarı (11a), açıklık alan, 500 m, 1.5.2016, S.Yağmur 203, KASOF 641.

103. M. orbicularis (L.) Bart. : Paralık

KSÜ Orman F.-i̇̈BF arası (23b), açıklık alan, $523 \mathrm{~m}, 19.4 .2016$, S.Yağmur 30, KASOF 642; KSÜ Ziraat F. civarı (12c), açıklık alan, 519 m, 21.4.2016, S.Yağmur 44, KASOF 643; KSÜ Ziraat F. Terasları civarı (11b), yol kenarı, $510 \mathrm{~m}$, 1.5.2016, S.Yağmur 171, KASOF 644; KSÜ Spor sahası etrafı (22c), açıklık alan, $535 \mathrm{~m}$, 27.04.2017, S.Yağmur 279, KASOF 645.

104. M. polymorpha L. var. vulgaris (Benth.) Shinners : Kurkyonca KSÜ Orman F.-ï̇BF arası (23b), açıklık alan, $537 \mathrm{~m}, 19.4 .2016$, S.Yağmur 27, KASOF 646; KSÜ Orman F. İ̈̇BF arası (23b), açıklık alan, $525 \mathrm{~m}, 19.4 .2016$, S.Yağmur 31, KASOF 647

105. $M$. radiata L. : Hilal yonca

KSÜ Ziraat F. Terasları civarı (11a), açıklık alan, 500 m, 1.5.2016, S.Yağmur 202, KASOF 648, Ir.-Tur. el.

106. M. rigidula (L.) All. var. cinerascens (Jord.) Rouy

KSÜ Ziraat F. civarı (12c), yol kenarı, 528 m, 23.3.2016, S.Yağmur 5, KASOF 649; KSÜ Ziraat F. civarı (12c), açıklık alan, $530 \mathrm{~m}$, 21.4.2016, S.Yağmur 45, KASOF 650; KSÜ Ziraat F. Terasları civarı (11b), yol kenarı, 510 m, 1.5.2016, S.Yağmur 172, KASOF 651.

107. M. sativa L. subsp. sativa

KSÜ Orman F.- İ̈BF arası (23b), yol kenarı, $535 \mathrm{~m}, 8.6 .2016$, S.Yağmur 233, KASOF 652; KSÜ Ziraat F. arkası (13a), açıklık alan, $513 \mathrm{~m}, 24.10 .2016$, S.Yağmur 237, KASOF 653

108. M. truncatula Gaertn. var. longiaculeata Urb.

KSÜ Ziraat F. Terasları civarı (11b), yol kenarı, 510 m, 1.5.2016, S.Yağmur 164, KASOF 654, Medit. el.

109. Melilotus indica (L.) All. : Tas yoncası

KSÜ Kafeterya altı (14d), açıklık alan, 525 m, 23.4.2016, S.Yağmur 105, KASOF 655.

110. Melilotus officinalis (L.) Desr. : Kokulu yonca

KSÜ İlahiyat F.-Alakart arası (23c), orman içi açıklık, $529 \mathrm{~m}$, 01.06.2017, S.Yağmur 371, KASOF 656.

111. Onobrychis caput-galli (L.) Lam. : Pitrak korunga

KSÜ Ziraat F. arkası (12b), açıklık alan, 513 m, 28.4.2016, S.Yağmur 122, KASOF 657; KSÜ Ziraat F. Terasları civarı (11b), yol kenarı, 510 m, 1.5.2016, S.Yağmur 168, KASOF 658, Medit. el.

112. Ononis pubescens L. : Havlı örsele

KSÜ Ziraat F. arkası (12b), açıklık alan, 513 m, 28.4.2016, S.Yağmur 152, KASOF 659; KSÜ Ziraat F. Terasları civarı (11b), yol kenarı, 510 m, 1.5.2016, S.Yağmur 174, KASOF 660; KSÜ Yabancı Diller F. civarı (23a), yol kenarı, 540 m, 8.6.2016, S.Yağmur 222, KASOF 661, Medit. el.

113. O. spinosa L. subsp. leiosperma (Boiss.) Sirj. : Demirdelen
KSÜ Yabancı Diller F. civarı (23a), yol kenarı, 534 m, 08.06.2016, S.Yağmur 265, KASOF 662.

114. Pisum sativum L. subsp. elatius (Bieb.) Aschers. et Graebn. var. brevipedunculatum Davis et Meikle : Bezelye

KSÜ Spor sahası etrafı (26d), açıklık alan, 532 m, 27.04.2017, S.Yağmur 271, KASOF 663.

115. $P$. sativum L. subsp. elatius (BIEB.) aschers. et Graebn. var. pumilio Meikle

KSÜ Ziraat F. civarı (12c), açıklık alan, 511 m, 21.4.2016, S.Yağmur 41, KASOF 664.

116. Psoralea bituminosa L. : Asfaltotu

KSÜ Ziraat F. arkası (12b), açıklık alan, 513 m, 28.4.2016, S.Yağmur 128 , KASOF 665, Medit. el.

117. Robinia hispida L. : Kıllı akasya

KSÜ Orman F. önü (12d), peyzaj düzenlemeleri, 527 m, 18.05.2017, S.Yağmur 344, KASOF 666, Egzotik.

118. $R$. pseudoacacia L. : Yalancı akasya

KSÜ Orman F. önü (12d), peyzaj düzenlemeleri, 527 m, 18.05.2017, S.Yağmur 345, KASOF 667, Egzotik.

119. Scorpiurus muricatus L. var. subvillosus (L.) Fiori Koyundücüğ̈

KSÜ Orman F- İ̈BF arası (23b), açılık alan, $535 \mathrm{~m}, 18.4 .2016$, S.Yağmur 25, KASOF 668; KSÜ Ziraat F. Terasları civarı (11a), açılklı alan, 505 m, 1.5.2016, S.Yağmur 187, KASOF 669, Medit. el. 120. Securigera securidaca (L.) Degen et Dã-Rf. : Körigen

KSÜ Ziraat F. civarı (12c), açıklık alan, $521 \mathrm{~m}, 21.4 .2016$, S.Yağmur 49, KASOF 670; KSÜ Ziraat F. arkası (12a), açıklık alan, $514 \mathrm{~m}$, 26.4.2016, S.Yağmur 116, KASOF 671; KSÜ Ziraat F. arkası (12b), açıklık alan, 513 m, 28.4.2016, S.Yağmur 151, KASOF 672; KSÜ Ziraat F. Terasları civarı (11b), yol kenarı, $510 \mathrm{~m}, 1.5 .2016$, S.Yağmur 167, KASOF 673.

121. Spartium junceum L. : Katır Tırnağ

KSÜ Orman F.- İ̈BF arası (23b), açıklık alan, 532 m, 19.4.2016, S.Yağmur 26, KASOF 674, Medit. el.

122. Trifolium campestre Schreb. : Üंçül

KSÜ Kafeterya altı (14d), açıklık alan, 525 m, 23.4.2016, S.Yağmur 96, KASOF 675; KSÜ Ziraat F. arkası (12b), açıklık alan, $513 \mathrm{~m}$, 28.4.2016, S.Yağmur 145, KASOF 676; KSÜ Spor sahası etrafı (22c), açıklık alan, 539 m, 27.04.2017, S.Yağmur 276, KASOF 677.

123. T. repens L. var. repens : Ak üçül

KSÜ Spor sahası etrafı (26d), açıklık alan, 536 m, 27.04.2017, S.Yağmur 272, KASOF 678

124. T. resupinatum L. var. resupinatum : Anadolu üçgülü

KSÜ Orman F.- İ̈BF arası (23b), açıklık alan, 538 m, 19.4.2016, S.Yağmur 29, KASOF 679; KSÜ Ziraat F. civarı (12c), açıklık alan, $521 \mathrm{~m}, 21.4 .2016$, S.Yağmur 57, KASOF 680; KSÜ Ziraat F. arkası (12b), açıklık alan, 513 m, 28.4.2016, S.Yağmur 154, KASOF 681.

125. T. spumosum L. : Kese yonca

KSÜ Orman F.- İ̈BF arası (24a), açıklık alan, 528 m, 18.4.2016, S.Yağmur 16, KASOF 682; KSÜ Ziraat F. civarı (12c), açılılı alan, $531 \mathrm{~m}, 21.4 .2016$, S.Yağmur 50, KASOF 683; KSÜ Ziraat F. Terasları civarı (11b), yol kenarı, 510 m, 1.5.2016, S.Yağmur 161, KASOF 684, Medit. el.

126. T. tomentosum L. : Yünlü yonca

KSÜ Spor sahası etrafı (22c), açıklık alan, $539 \mathrm{~m}, 27.04 .2017$, S.Yağmur 277, KASOF 685.

127. Trigonella kotschyi Fenzl : Akboyotu

KSÜ Ziraat F. civarı (12c), yol kenarı, 523 m, 23.3.2016, S.Yağmur 3, KASOF 686; KSÜ Kafeterya altı (14d), açıklık alan, 525 m, 23.4.2016, S.Yağmur 89, KASOF 687; KSÜ Ziraat F. arkası (12a), açıklık alan, $514 \mathrm{~m}, 26.4 .2016$, S.Yağmur 111, KASOF 688, Endemik, IUCN: LC, Ir.-Tur. el.

128. T. monspeliaca L. : Som çemenotu

KSÜ Ziraat F. civarı (12c), yol kenarı, 520 m, 23.3.2016, S.Yağmur 2, KASOF 689; KSÜ Kafeterya altı (14d), açıklık alan, $522 \mathrm{~m}$, 23.4.2016, S.Yağmur 77, KASOF 690, Medit. el.

129. T. spicata Sibth. et Sm. : Başak boyotu

KSÜ Ziraat F. Terasları civarı (11a), açıklık alan, 505 m, 1.5.2016, S.Yağmur 193, KASOF 691, East Medit. el.

130. Vicia anatolica Turrill : Yılan fiği

KSÜ Ziraat F. civarı (12c), açıklık alan, 531 m, 21.4.2016, S.Yağmur 51, KASOF 692, Ir.-Tur. el. 
131. V. faba L. : Bakla

KSÜ Kafeterya altı (14d), açıklık alan, 525 m, 23.04.2016, S.Yağmur 258, KASOF 693.

132. V. grandiflora Scop. var. grandiflora : Koca bakla

KSÜ Ziraat F. Terasları civarı (11a), açıklık alan, 505 m, 1.5.2016, S.Yağmur 191, KASOF 694, East Medit. el.

133. $V$. noeana Reuter ex Boiss. var. noeana

KSÜ Tıp F. Civarı (25b), taşlıklı alan, 531 m, 04.04.2017, S.Yağmur 247, KASOF 695, Ir.-Tur. el.

134. V. peregrina L. : Kavli

KSÜ Ziraat F. civarı (12c), yol kenarı, 523 m, 23.3.2016, S.Yağmur 4, KASOF 696

135. V. sativa L. subsp. nigra (L.) Ehrh. var. nigra : Eşek gürülü

KSÜ Orman F--İ̈BF arası (23b), açıklık alan, 562 m, 13.4.2016, S.Yağmur 10, KASOF 697.

136. V. sativa L. subsp. nigra (L.) Ehrh. var. segetalis (Thuill.) Ser. ex Dc.

KSÜ Kafeterya altı (14d), açıklık alan, 522 m, 23.4.2016, S.Yağmur 83, KASOF 698; KSÜ Ziraat F. Terasları civarı (11b), yol kenarı, $510 \mathrm{~m}, 1.5 .2016$, S.Yağmur 162, KASOF 699.

137. Wisteria sinensis (Sims) Dc.

KSÜ Orman F.-İ̇BF arası (23b), peyzaj düzenlemeleri, $538 \mathrm{~m}$, 18.05.2017, S.Yağmur 353, KASOF 700, Egzotik.

\section{V.3. Myrtales \\ 29. Myrtaceae}

138. Eucalyptus camaldulensis Dehnh. : Sitma ağacı

KSÜ Besyo arkası (27b), ağaçlık alan, 522 m, 18.05.2017, S.Yağmur 325, KASOF 701, Egzotik.

139. Myrtus communis L. subsp. communis : Mersin

KSÜ Ziraat F. arkası (12b), açıklık alan, 507 m, 07.06.2017, S.Yağmur 391, KASOF 702.

\section{Punicaceae}

140. Punica granatum L. : Nar

KSÜ İlahiyat F.-Alakart arası (23c), açıklık alan, 528 m, 07.06.2017, S.Yağmur 385, KASOF 703

\section{Onagraceae}

\section{Epilobium hirsutum L. : Hasanhüseyin çiçeği}

KSÜ Ziraat F. arkası (12b), açıklık alan, 513 m, 24.10.2016, S.Yağmur 239, KASOF 704

142. E. parviflorum Schreber : Iraz yakıotu

KSÜ Ziraat F. arkası (12b), açıklık alan, 513 m, 28.4.2016, S.Yağmur 138, KASOF 705; KSÜ Ziraat F. Terasları civarı (11b), yol kenarı, 510 m, 1.5.2016, S.Yağmur 182, KASOF 706; KSÜ Yabancı Diller F. civarı (23a), yol kenarı, 534 m, 8.6.2016, S.Yağmur 228, KASOF 707. 143. Gaura lindheimeri Engelm. \& A.Gray

KSÜ Orman F.- İ̈BF arkası (23b), açıklık alan, 540 m, 24.04.2015, S.Yağmur 290, KASOF 708, Egzotik.

$$
\begin{aligned}
& \text { V.4. Cornales } \\
& \text { 32. Cornaceae }
\end{aligned}
$$

144. Cornus kousa F.Buerger ex Hance

KSÜ Yabancı Diller F. civarı (23a), peyzaj düzenlemeleri, $532 \mathrm{~m}$, 02.05.2013, S.Yağmur 283, KASOF 709; KSÜ Rektörlük binası civarı (24c), peyzaj düzenlemeleri, $536 \mathrm{~m}, 18.05 .2017$, S.Yağmur 310, KASOF 710, Egzotik.

$$
\begin{aligned}
& \text { V.5. Euphorbiales } \\
& \text { 33. Euphorbiaceae }
\end{aligned}
$$

\section{A. telephioides L. : Duvarnohutu}

KSÜ Ziraat F. civarı (12c), açıklık alan, 524 m, 21.4.2016, S.Yağmur 46, KASOF 711; KSÜ Kafeterya altı (14d), açıklık alan, 525 m, 23.4.2016, S.Yağmur 93, KASOF 712; KSÜ Ziraat F. arkası (12a), açıklık alan, 514 m, 26.4.2016, S.Yağmur 109, KASOF 713; KSÜ
Ziraat F. arkası (12b), açıklık alan, 513 m, 28.4.2016, S.Yağmur 153, KASOF 714

146. Euphorbia aleppica L. : Haşul

KSÜ Ziraat F. civarı (12c), açıklık alan, 523 m, 21.4.2016, S.Yağmur 42, KASOF 715; KSÜ Kafeterya altı (14d), açıklık alan, $525 \mathrm{~m}$, 23.4.2016, S.Yağmur 102, KASOF 716; KSÜ Yabancı Diller F. civarı (22b), açıklık alan, 540 m, 11.5.2016, S.Yağmur 213, KASOF 717.

147. E. helioscopia L. : Feribanotu

KSÜ Yabancı Diller F. civarı (22c), yol kenarı, 539 m, 20.4.2016, S.Yağmur 39, KASOF 718

148. E. peplus L. var. peplus : Bahçe sütleğeni

KSÜ Orman F.-İ̈BF arası (24a), açıklık alan, $543 \mathrm{~m}, 18.4 .2016$ S.Yağmur 20, KASOF 719.

149. E. taurinensis All. : Tilki sütleğeni

KSÜ Ziraat F. arkası (12b), açıklık alan, 513 m, 28.4.2016, S.Yağmur 123, KASOF 720.

\section{V.6. Rhamnales \\ 34. Rhamnaceae}

150. Paliurus spina-christi Miller : Karaçalı

KSÜ Kafeterya altı (14d), ağaçlık alan, 515 m, 18.05.2017, S.Yağmur 336, KASOF 721.

151. Rhamnus cathartica L. : Cehri

KSÜ Illahiyat F.-Alakart arası (23c), açıklık alan, 528 m, 07.06.2017, S.Yağmur 398, KASOF 722, Egzotik.

\section{Vitaceae}

152. Vitis vinifera L. : Asma

KSÜ İlahiyat F.-Alakart arası (23c), açıklık alan, 528 m, 07.06.2017, S.Yağmur 387, KASOF 723.

\section{V.7. Linales \\ 36. Linaceae}

\section{Linum nodiflorum L. : Yaban keten}

KSÜ İlahiyat F.-Alakart arası (23c), orman içi açıklık, $529 \mathrm{~m}$, 24.04.2015, S.Yağmur 300, KASOF 724, Medit. el.

154. L. pubescens Banks et Sol. subsp. pubescens

KSÜ Ziraat F. arkası (12a), açıklık alan, 525 m, 23.4.2016, S.Yağmur 107, KASOF 725; KSÜ Ilahiyat F.-Alakart arası (23c), orman içi açıklık, 529 m, 24.04.2015, S.Yağmur 301, KASOF 726, East Medit.

$$
\begin{aligned}
& \text { V.8. Sapindales } \\
& \text { 37. Sapindaceae }
\end{aligned}
$$

155. Koelreuteria paniculata Laxm. : Güvey kandili

KSÜ İlahiyat F.-Alakart arası (23c), açıklık alan, 528 m, 07.06.2017, S.Yağmur 396, KASOF 727, Egzotik.

\section{Aceraceae}

156. Acer negundo L. : Dişbudak yapraklı akçaağaç

KSÜ Rektörlük binası civarı (24b), ağaçlık alan, 531 m, 18.05.2017, S.Yağmur 309, KASOF 728, Egzotik.

157. A. buergerianum Miq.

KSÜ Orman F. önü (12d), peyzaj düzenlemeleri, 527 m, 01.06.2017, S.Yağmur 402, KASOF 729, Egzotik.

158. A. pseudoplatanus L. : Dağ akçaağacı

KSÜ Orman F. önü (12d), peyzaj düzenlemeleri, 527 m, 01.06.2017, S.Yağmur 401, KASOF 730, Egzotik, Euro-Sib. el.

\section{Anacardiaceae}

159. Rhus coriaria L. : Sumak

KSÜ İlahiyat F. arkası (22c), açıklık alan, $522 \mathrm{~m}, 07.06 .2017$, S.Yağmur 378, KASOF 731

40. Meliaceae 
160. Melia azedarach L. : Tespih ağac

KSÜ Rektörlük binası civarı (24b), peyzaj düzenlemeleri, $530 \mathrm{~m}$, 18.05.2017, S.Yağmur 333, KASOF 732, Egzotik

\section{Rutaceae}

161. Haplophyllum buxbaumii (Poiret) G. Don subsp. buxbaumii (Poiret) G. Don

KSÜ Yabancı Diller F. civarı (22b), açıklık alan, 539 m, 11.5.2016, S.Yağmur 208, KASOF 733; KSÜ Yabancı Diller F. civarı (23a), yol kenarı, 540 m, 8.6.2016, S.Yağmur 227, KASOF 734

$$
\begin{aligned}
& \text { V.9. Geraniales } \\
& \text { 42. Oxalidaceae }
\end{aligned}
$$

162. Oxalis corniculata L. : Sarı ekşiyonca

KSÜ Orman F.- İİBF arası (24a), açıklık alan, 543 m, 18.4.2016, S.Yağmur 23, KASOF 735

\section{Geraniaceae}

163. Erodium acaule (L.) Becherer et Thell. : Leylekgagası

KSÜ Ziraat F. arkası (12a), açıklık alan, 514 m, 26.4.2016, S. Yağmur 115, KASOF 736; KSÜ Ziraat F. Terasları civarı (11b), yol kenarı, 510 m, 1.5.2016, S.Yağmur 175, KASOF 737, Medit. el.

164. Geranium macrostylum Boiss. : Turna Gagası

KSÜ İlahiyat F.-Alakart arası (23c), orman içi açıklık, $532 \mathrm{~m}$, 24.04.2015, S.Yağmur 291, KASOF 738, East Medit. (mt.) el.

165. G. rotundifolium L. : Helilok

KSÜ Kafeterya altı (14a), yol kenarı, 521 m, 23.4.2016, S.Yağmur 74, KASOF 739.

166. G. tuberosum L. subsp. tuberosum : Çakmuz

KSÜ İlahiyat F. arkası (22c), açıklık alan, 531 m, 12.04.2017, S.Yağmur 253, KASOF 740.

$$
\begin{aligned}
& \text { V.10. Apiales } \\
& \text { 44. Araliaceae }
\end{aligned}
$$

167. Hedera helix L. : Duvar sarmaşı̆̆ı

KSÜ İİF civarı (24a), açıklık alan, 543 m, 07.06.2017, S.Yağmur 377 , KASOF 741.

\section{Apiaceae}

\section{Ainsworthia trachycarpa Boiss. : Boz kafkalida}

KSÜ Kafeterya altı (14a), yol kenarı, 514 m, 23.4.2016, S.Yağmur 65, KASOF 742; KSÜ Ziraat F. arkası (12a), açıklık alan, 514 m, 26.4.2016, S.Yağmur 108, KASOF 743; KSÜ Ziraat F. arkası (12b), açıklık alan, 513 m, 28.4.2016, S.Yağmur 142, KASOF 744; KSÜ Ziraat F. Terasları civarı (11b), yol kenarı, 510 m, 1.5.2016, S.Yağmur 156, KASOF 745, East Medit. el.

169. Ammi majus L. : Kürdanotu

KSÜ Yabancı Diller F. civarı (23a), yol kenarı, 539 m, 8.6.2016, S.Yağmur 223, KASOF 746, Medit. el.

170. Artedia squamata L. : Karabenek

KSÜ Ziraat F. arkası (13d), yol kenarı, 527 m, 01.06.2017, S.Yağmur 363, KASOF 747.

171. Bupleurum croceum Fenzl : Çiğdem şeytanı

KSÜ Ziraat F. arkası (12b), açıklık alan, 513 m, 28.4.2016, S.Yağmur 150, KASOF 748, Ir.-Tur. el.

172. B. falcatum L. subsp. persicum (Boiss.) Koso-Pol. subsp. : Kayaçatalı

KSÜ İlahiyat F.-Alakart arası (23c), orman içi açıklık, 530 m, 01.06.2017, S.Yağmur 364, KASOF 749.

\section{B. rotundifolium L. : Soluk şeytanayağı}

KSÜ Ziraat F. arkası (12a), açıklık alan, 514 m, 26.4.2016, S.Yağmur 113, KASOF 750; KSÜ Ziraat F. Terasları civarı (11b), yol kenarı, 509 m, 1.5.2016, S.Yağmur 180, KASOF 751; KSÜ Yabancı Diller F. civarı (22b), açıklık alan, 540 m, 11.5.2016, S.Yağmur 211, KASOF 752 .

174. Coriandrum sativum L. : Kişniş
KSÜ Yabancı Diller F. civarı (22b), açıklık alan, 540 m, 11.5.2016, S.Yağmur 212, KASOF 753.

175. Eryngium campestre L. var. virens Link : Kirsenet

KSÜ Yabancı Diller F. civarı (23a), yol kenarı, 541 m, 8.6.2016, S.Yağmur 221, KASOF 754.

176. Tordylium syriacum L. : Boz davulotu

KSÜ İlahiyat F.-Alakart arası (23d), orman içi açıklık, $536 \mathrm{~m}$, 19.04.2017, S.Yağmur 269, KASOF 755, East Medit. el.

177. Torilis arvensis (Huds.) Link subsp. arvensis : Dercikotu

KSÜ Ziraat F. civarı (12c), açıklık alan, 522 m, 21.4.2016, S.Yağmur 47, KASOF 756; KSÜ Ziraat F. arkası (12b), açıklık alan, $513 \mathrm{~m}$ 28.4.2016, S.Yağmur 134, KASOF 75.

\section{Asteridae \\ VI.1. Gentianales \\ 46. Apocynaceae}

178. Nerium oleander L. : Zakkum

KSÜ Ziraat F. arkası (13a), peyzaj düzenlemeleri, $511 \mathrm{~m}, 18.05 .2017$, S.Yağmur 335, KASOF 758, Medit. el.

\section{VI.2. Solanales \\ 47. Convolvulaceae}

179. Convolvulus arvensis L. : Tarla sarmaşığ

KSÜ Yabancı Diller F. civarı (22b), açıklık alan, 538 m, 11.5.2016, S.Yağmur 207, KASOF 759.

180. C. betonicifolius Miller subsp. betonicifolius : Büyük yayllgan KSÜ Orman F.-íİF arası (23b), açıklık alan, 528 m, 19.4.2016, S.Yağmur 33, KASOF 760; KSÜ Ziraat F. arkası (12b), açıklık alan, 513 m, 28.4.2016, S.Yağmur 143, KASOF 761; KSÜ Ziraat F. arkası (12b), açıklık alan, 513 m, 24.10.2016, S.Yağmur 242, KASOF 762. 181. C. betonicifolius Miller subsp. peduncularis (Boiss.) Parris KSÜ Kafeterya altı (14d), açıklık alan, 522 m, 23.4.2016, S.Yağmur 86, KASOF 763, Ir.-Tur. el.

182. C. dorycnium L. subsp. oxysepalus (Boiss. Rech. Fil. : Bağlıkotu KSÜ Yabancı Diller F. civarı (23a), yol kenarı, 535 m, 8.6.2016, S.Yağmur 224, KASOF 764, East Medit. el.

\section{VI.3. Lamiales}

48. Boraginaceae

183. Anchusa azurea Miller var. azurea : Sığırdili

KSÜ Orman F.-İIBF arası (23b), açıklık alan, 559 m, 13.4.2016, S.Yağmur 11, KASOF 765; KSÜ Ziraat F. arkası (12b), açıklık alan, 513 m, 28.4.2016, S.Yağmur 129, KASOF 766.

184. A. strigosa Labill. : Gelezan

KSÜ Ziraat F. arkası (12b), açıklık alan, 513 m, 28.4.2016, S. Yağmur 125, KASOF 767; KSÜ Ziraat F. arkası (12b), açıklık alan, 513 m, 28.4.2016, S.Yağmur 126, KASOF 768; KSÜ Ziraat F. Terasları civarı (11b), yol kenarı, 510 m, 1.5.2016, S.Yağmur 165, KASOF 769; KSÜ İlahiyat F. arkası (22c), açıklık alan, $530 \mathrm{~m}, 12.04 .2017$, S.Yağmur 252, KASOF 770.

185. Heliotropium bovei Boiss

KSÜ Ziraat F. Terasları civarı (11b), yol kenarı, 510 m, 1.5.2016, S.Yağmur 163, KASOF 771; KSÜ Yabancı Diller F. civarı (23a), yol kenarı, 534 m, 8.6.2016, S.Yağmur 230, KASOF 772, East Medit. el.

\section{Verbenaceae}

186. Lantana camara L. : Çalıminesi

KSÜ Kafeterya altı (14d), açıklık alan, 525 m, 07.06.2017, S.Yağmur 389, KASOF 773, Egzotik.

\section{Lamiaceae}

187. Ajuga chamaepitys (L.) Schreber subsp. laevigata (Banks et Sol.) P. H. Davis : Kelmayasıl

KSÜ Ziraat F. Terasları civarı (11b), yol kenarı, 510 m, 1.5.2016, S.Yağmur 170, KASOF 774, Ir.-Tur. el.

188. Lamium amplexicaule L. : Ballıbaba, Baltutan 
KSÜ Ziraat F. civarı (12c), yol kenarı, 523 m, 06.04.2017, S.Yağmur 248, KASOF 775, Euro-Sib. el.

189. Lavandula stoechas $\mathrm{L}$. subsp. stoechas : Karabas

KSÜ Orman F.- İ̈BF arası (23b), açıklık alan, 526 m, 19.4.2016,

S.Yağmur 32, KASOF 776, Medit. el.

190. L. angustifolia Miller subsp. angustifolia : Lavanta

KSÜ Orman F.- İIBFF F. arası (24a), yol kenarı, 527 m, 01.06.2017, S.Yağmur 369, KASOF 777, Egzotik.

191. Mentha longifolia (L.) Hudson subsp. typhoides (Briq.) Harley var. typhoides (L.) Hudson : Dere nanesi

KSÜ Ziraat F. arkası (13a), açıklık alan, 513 m, 24.10.2016, S.Yağmur 238, KASOF 778

192. Moluccella laevis L. : Çanakçiçeği

KSÜ Yabancı Diller F. civarı (22b), açıklık alan, 500 m, 1.5.2016, S.Yağmur 204, KASOF 779; KSÜ Yabancı Diller F. civarı (22b), açlklık alan, $540 \mathrm{~m}, 11.5 .2016$, S.Yağmur 215, KASOF 780; KSÜ İlahiyat F.-Alakart arası (23c), açıklık alan, 538 m, 24.04.2015, S.Yağmur 302, KASOF 781, Ir.-Tur. el.

193. Rosmarinus officinalis L. : Biberiye

KSÜ Tıp F.-Güzel Sanatlar F. arası (26a), peyzaj düzenlemeleri, 528 m, 18.05.2017, S.Yağmur 346, KASOF 782, Medit. el.

194. Salvia viridis L. : Adaçayı, Zarif şalba

KSÜ İlahiyat F. arkası (22d), açıklık alan, $527 \mathrm{~m}, 12.04 .2017$, S.Yağmur 257, KASOF 783; KSÜ İlahiyat F.-Alakart arası (23c), orman içi açıklık, 532 m, 24.04.2015, S.Yağmur 304, KASOF 784, Medit. el.

195. Teucrium fruticans L. : Kısamahmut

KSÜ Yabancı Diller F. civarı (23a), peyzaj düzenlemeleri, $529 \mathrm{~m}$, 24.04.2015, S.Yağmur 307, KASOF 785; KSÜ Orman F. önü (12d), peyzaj düzenlemeleri, $527 \mathrm{~m}$, 01.06.2017, S.Yağmur 359, KASOF 786, Egzotik.

\section{VI.4. Plantaginales \\ 51. Plantaginaceae}

196. Plantago lanceolata L. : Sinir out, Damarlica

KSÜ Kafeterya altı (14a), açıklık alan, 521 m, 21.4.2016, S.Yağmur 59, KASOF 787; KSÜ Ziraat F. arkası (12a), açıklık alan, 514 m, 26.4.2016, S.Yağmur 110, KASOF 788

\section{VI.5. Scrophulariales} 52. Oleaceae

197. Forsythia $x$ intermedia Zabel : Altın çanak

KSÜ Kafeterya üst yol (25a), peyzaj düzenlemeleri, $528 \mathrm{~m}$, 01.06.2017, S.Yağmur 357, KASOF 789, Egzotik.

198. Fraxinus americana L. : Amerikan Dişbudağ

KSÜ Tıp F.-Güzel Sanatlar F. arası (26a), ağaçlık alan, $527 \mathrm{~m}$, 18.05.2017, S.Yağmur 327, KASOF 790, Ir.-Tur. el., Egzotik.

199. Jasminum fruticans $\mathrm{L}$. : Sarı Ciçekli Yasemin

KSÜ Besyo-Güzel Sanatlar F. arası (26d), açıklık alan, 538 m, 18.05.2017, S.Yağmur 328, KASOF 791, Medit. el.

200. Ligustrum japonicum Thunb. : Japon Kurtbağrı

KSÜ Rektörlük binası civarı (24a), peyzaj düzenlemeleri, $545 \mathrm{~m}$, 07.06.2017, S.Yağmur 382, KASOF 792, Egzotik.

201. Olea europaea L. var. europaea : Zeytin

KSÜ İlahiyat F.-Alakart arası (23c), açıklık alan, 528 m, 07.06.2017, S.Yağmur 386, KASOF 793.

202. Syringa vulgaris L. (Yaygin Leylak) : Yaygın leylak

KSÜ Spor sahası etrafı (26c), açıklık alan, 528 m, 31.03.2017, S.Yağmur 306, KASOF 794; KSÜ Besyo-Güzel Sanatlar F. arası (26c), açıklık alan, 532 m, 18.05.2017, S.Yağmur 349, KASOF 795, Egzotik.

\section{Scrophulariaceae}

203. Linaria simplex (Willd.) Dc. : Yalın nevruzotu

KSÜ İlahiyat F.-Alakart arası (23c), orman içi açıklık, $526 \mathrm{~m}$, 24.04.2015, S.Yağmur 299, KASOF 796, Medit. el.

204. L. chalepensis (L.) Miller var. chalepensis : Halep nevruzotu

KSÜ Kafeterya altı (14d), açıklık alan, 522 m, 23.4.2016, S.Yağmur 79, KASOF 797, East Medit. el.
205. Verbascum sp. : Sığırkuyruğu

KSÜ Ziraat F. civarı (12c), açıklık alan, 513 m, 24.10.2016, S.Yağmur 243, KASOF 798.

206. Veronica persica Poiret: Circamuk

KSÜ Orman F.-İ̈BF arası (23b), açıklık alan, 543 m, 18.4.2016, S.Yağmur 24, KASOF 799.

207. Paulownia tomentosa (Thunb.) Sieb. \& Zucc. ex Steud. : Tüylü Pavlonya

KSÜ Rektörlük binası civarı (24a), peyzaj düzenlemeleri, $545 \mathrm{~m}$, 07.06.2017, S.Yağmur 388, KASOF 800, Egzotik.

\section{Bignoniaceae}

208. Campsis radicans (L.) Seem. : Acemborusu

KSÜ İlahiyat F.-Alakart arası (23c), açıklık alan, 528 m, 07.06.2017, S.Yağmur 399, KASOF 801; KSÜ Aslanlı Park (24b), peyzaj alanı, 533 m, 07.06.2017, S.Yağmur 407, KASOF 802, Egzotik.

209. Catalpa bignonioides Walter. : Katalpa

KSÜ Rektörlük binası civarı (24a), peyzaj düzenlemeleri, $542 \mathrm{~m}$, 18.05.2017, S.Yağmur 319, KASOF 803, Egzotik.

\section{VI.6. Campanulales 55. Nyctaginaceae}

210. Bougainvillea spectabilis Willd. : Gelin duvağ KSÜ ÜSKIM binası civarı (23b), açıklık alan, 536 m, 07.06.2017, S.Yağmur 381, KASOF 804, Egzotik.

\section{Campanulaceae}

211. Legousia pentagonia (L.) Thellung : Kadınaynası KSÜ Ziraat F. Terasları civarı (11b), yol kenarı, $510 \mathrm{~m}, 1.5 .2016$, S.Yağmur 176, KASOF 805; KSÜ Yabancı Diller F. civarı (22b), açıklık alan, $540 \mathrm{~m}, 11.5 .2016$, S.Yağmur 216, KASOF 806. 212. L. falcata (Ten.) Fritsch : Eğri kadınaynası

KSÜ Orman F.-ï̇BF arası (24a), yol kenarı, 527 m, 24.04.2015, S.Yağmur 298, KASOF 807, Medit. el.

\section{VI.7. Rubiales \\ 57. Rubiaceae}

213. Callipeltis cucullaria (L.) Steven : Nermik

KSÜ Kafeterya altı (14d), açıklık alan, 525 m, 23.4.2016, S.Yağmur 94, KASOF 808, Ir.-Tur. el.

214. Galium aparine L. : Çobansüzgeci

KSÜ Kafeterya altı (14d), açıklık alan, 522 m, 23.4.2016, S.Yağmur 84, KASOF 809; KSÜ Ziraat F. Terasları civarı (11b), açıklık alan, 505 m, 1.5.2016, S.Yağmur 184, KASOF 810; KSÜ Ziraat F. arkası (12b), açıklık alan, 513 m, 28.4.2016, S.Yağmur 132, KASOF 811. 215. G. samuelssonii Ehrend. var. samuelssonii : Akça iplikçik KSÜ Yabancı Diller F. civarı (22b), açıklık alan, 540 m, 11.5.2016, S.Yağmur 219, KASOF 812, East Medit. el.

216. Sherardia arvensis L. : Gökörenotu

KSÜ Kafeterya altı (14a), yol kenarı, 514 m, 23.4.2016, S.Yağmur 66, KASOF 813; KSÜ Kafeterya altı (14a), yol kenarı, $521 \mathrm{~m}$, 23.4.2016, S.Yağmur 73, KASOF 814; KSÜ Ziraat F. civarı (12c), açıklık alan, 526 m, 21.4.2016, S.Yağmur 52, KASOF 815, Medit. el.

VI.8. Dipsacales

58. Caprifoliaceae

217. Viburnum opulus L. : Kartopu

KSÜ Orman F.-ïiBF arası (23b), peyzaj düzenlemeleri, $535 \mathrm{~m}$, 18.05.2017, S.Yağmur 351, KASOF 816, Euro-Sib. el.

218. V. tinus $L$.

KSÜ Orman F.-İİB arası (23b), peyzaj düzenlemeleri, $535 \mathrm{~m}$, 01.06.2017, S.Yağmur 361, KASOF 817, Egzotik, Medit. el.

\section{Valerianaceae}

219. Valerianella discoidea (L.) Loisel : Ekin kuzukevreği 
KSÜ Kafeterya altı (14a), yol kenarı, 514 m, 23.4.2016, S.Yağmur 69, KASOF 818, Medit. el.

60. Dipsacaceae

220. Cephalaria syriaca (L.) Schrader : Pelemir

KSÜ Yabancı Diller F. civarı (22b), açıklık alan, 538 m, 11.5.2016, S.Yağmur 205, KASOF 819

221. Pterocephalus plumosus (L.) Coulter : Gök Cücükotu

KSÜ Yabancı Diller F. civarı (23a), yol kenarı, 537 m, 8.6.2016, S.Yağmur 231, KASOF 820

222. Scabiosa calocephala Boiss. : Uyuzotu

KSÜ Ziraat F. Terasları civarı (11a), açıklık alan, 500 m, 1.5.2016, S.Yağmur 201, KASOF 821, Ir.-Tur. el.

VI.9. Asterales

61. Asteraceae

223. Carduus argentatus L. : Gümüş dikeni

KSÜ Kafeterya altı (14d), açıklık alan, 525 m, 23.4.2016, S.Yağmur 92, KASOF 822, East Medit. el.

224. C. pycnocephalus L. subsp. breviphyllarius Davis : Eşek soymas1

KSÜ Yabancı Diller F. civarı (22c), yol kenarı, 539 m, 20.4.2016, S.Yağmur 38, KASOF 823; KSÜ Ziraat F. Terasları civarı (11a), açıklık alan, $505 \mathrm{~m}, 1.5 .2016$, S.Yağmur 195, KASOF 824.

225. Centaurea calcitrapa L. subsp. calcitrapa : Cobankaldıran

KSÜ Ziraat F. Terasları civarı (11a), açıklık alan, 505 m, 1.5.2016, S.Yağmur 188, KASOF 825; KSÜ Kafeterya altı (14d), açıklık alan, 525 m, 23.4.2016, S.Yağmur 100, KASOF 826; KSÜ Ziraat F. arkası (12b), açıklık alan, 515 m, 26.4.2016, S.Yağmur 120, KASOF 827, Medit. el.

226. C. solstitialis L. subsp. solstitialis : Cakırdikeni

KSÜ Yabancı Diller F. civarı (23a), yol kenarı, 542 m, 8.6.2016, S.Yağmur 226, KASOF 828

227. Chondrilla juncea L. var. juncea : Karakavuk

KSÜ Ziraat F. civarı (12c), açıklık alan, 513 m, 24.10.2016, S.Yağmur 244, KASOF 829.

228. Cichorium intybus L. : Hindiba

KSÜ İlahiyat F.-Alakart arası (23d), yol kenarı, 532 m, 01.06.2017, S.Yağmur 365, KASOF 830.

229. C. pumilum Jacq. : Dünek

KSÜ Ziraat F. Terasları civarı (11b), yol kenarı, 510 m, 1.5.2016, S.Yağmur 173, KASOF 831, East Medit. el.

230. Conyza canadensis (L.) Cronquist: Selviotu

KSÜ Ziraat F. arkası (12b), açıklık alan, 513 m, 24.10.2016, S.Yağmur 240, KASOF 832

231. Crepis alpina L. : Yürekotu

KSÜ Ziraat F. Terasları civarı (11b), yol kenarı, 510 m, 1.5.2016, S.Yağmur 159, KASOF 833

232. C. foetida L. subsp. rhoeadifolia (Bieb.) Celak. : Sakarkanak

KSÜ Kafeterya altı (14a), yol kenarı, 514 m, 23.4.2016, S.Yağmur 60, KASOF 834.

233. C. micrantha Czer. : Yedi kıskıs

KSÜ Kafeterya altı (14a), yol kenarı, 514 m, 23.4.2016, S.Yağmur 61 , KASOF 835.

234. C. sancta (L.) BABCOCK

KSÜ Orman F.-ïiBF arası (23b), açıklık alan, 560 m, 13.4.2016, S.Yağmur 12, KASOF 836; KSÜ İlahiyat F. arkası (22d), açıklık alan, $532 \mathrm{~m}, 12.04 .2017$, S.Yağmur 264, KASOF 837.

235. Crupina crupinastrum (Moris) Vis. : Gelindöndüren

KSÜ Kafeterya altı (14d), açıklık alan, 525 m, 23.4.2016, S.Yağmur 95, KASOF 838; KSÜ İlahiyat F.-Alakart arası (23c), orman içi açıklık, 530 m, 24.04.2015, S.Yağmur 288, KASOF 839.

236. Filago pyramidata L. : Ateşpamuğu

KSÜ Kafeterya altı (14d), açıklık alan, 525 m, 23.4.2016, S.Yağmur 104, KASOF 840

237. Lactuca serriola L. : Eşekhelvası

KSÜ Yabancı Diller F. civarı (22b), açıklık alan, 540 m, 11.5.2016,

S.Yağmur 209, KASOF 841, Euro-Sib. el.

238. Notobasis syriaca (L.) Cass. : Yavan kenger
KSÜ Yabancı Diller F. civarı (22b), açıklık alan, 540 m, 11.5.2016, S.Yağmur 218, KASOF 842, Medit. el.

239. Picnomon acarna (L.) Cass. : Kılçıkdiken

KSÜ İlahiyat F.-Alakart arası (23c), orman içi açıklık, $529 \mathrm{~m}$, 01.06.2017, S.Yağmur 372, KASOF 843, Medit. el.

240. Pulicaria arabica (L.) Cass. : Arap yaraotu

KSÜ Ziraat F. civarı (12c), açıklık alan, 513 m, 24.10.2016, S.Yağmur 245, KASOF 844.

241. Rhagadiolus stellatus (L.) Gaertner var. stellatus

Çatlakçanak

KSÜ İlahiyat F.-Alakart arası (23d), orman içi açıklık, $530 \mathrm{~m}$ 24.04.2015, S.Yağmur 303, KASOF 845; KSÜ Spor sahası etrafi (22c), açıklık alan, 539 m, 27.04.2017, S.Yağmur 278, KASOF 846 242. Santolina chamaecyparissus L. : Lavantin

KSÜ Orman F. İ̈̈BF arası (23b), açıklık alan, 540 m, 24.04.2015, S.Yağmur 305, KASOF 847, Egzotik, Medit. el.

243. Scolymus hispanicus L. : Şevketi bostan

KSÜ İlahiyat F.-Alakart arası (23c), açıklık alan, 538 m, 01.06.2017, S.Yağmur 373, KASOF 848, Medit. el.

244. Senecio vernalis Waldst. et Kit: Kanaryaotu

KSÜ Ziraat F. civarı (12c), yol kenarı, 520 m, 23.3.2016, S.Yağmur 1, KASOF 849; KSÜ Kafeterya altı (14a), yol kenarı, $514 \mathrm{~m}$, 23.4.2016, S.Yağmur 63, KASOF 850; KSÜ Ziraat F. Terasları civar (11b), açıklık alan, $513 \mathrm{~m}, 28.4 .2016$, S.Yağmur 155, KASOF 851; KSÜ Ziraat F. Terasları civarı (11b), yol kenarı, $510 \mathrm{~m}, 1.5 .2016$, S.Yağmur 179, KASOF 852; KSÜ İlahiyat F. arkası (22d), açıklık alan, $530 \mathrm{~m}, 12.04 .2017$, S.Yağmur 263, KASOF 853.

245. Silybum marianum (L.) Gaertner : Devedikeni

KSÜ İlahiyat F.-Alakart arası (23c), orman içi açıklık, $532 \mathrm{~m}$, 01.06.2017, S.Yağmur 375, KASOF 854, Medit. el.

246. Sonchus asper (L.) Hill subsp. glaucescens (Jordan) Ball : Gevirtlek

KSÜ Yabancı Diller F. civarı (23a), yol kenarı, 534 m, 8.6.2016, S.Yağmur 225, KASOF 855.

247. Sonchus oleraceus L. : Kuzugevreği

KSÜ Orman F.-ï̇BF arası (23b), açıklık alan, 562 m, 13.4.2016, S.Yağmur 13, KASOF 856.

248. Taraxacum hellenicum Dahlst. : Leblebiotu

KSÜ Ziraat F. civarı (12c), açıklık alan, 520 m, 10.04.2017, S.Yağmur 249, KASOF 857, Medit. el.

249. Tragopogon longirostis Bisch. Ex Schultz Bip. var. longirostis Yemlik

KSÜ Ziraat F. arkası (12a), açıklık alan, 514 m, 26.4.2016, S.Yağmur 118, KASOF 858; KSÜ Ziraat F. arkası (12b), açklık alan, $513 \mathrm{~m}$, 28.4.2016, S.Yağmur 133, KASOF 859; KSÜ İlahiyat F.-Alakart arası (23c), orman içi açıklık, $535 \mathrm{~m}, 24.04 .2015$, S.Yağmur 308, KASOF 860.

250. Tripleurospermum tenuifolium (Kit.) Freyn : Akpapatya

KSÜ Yabancı Diller F. civarı (22c), yol kenarı, 539 m, 20.4.2016, S.Yağmur 37, KASOF 861; KSÜ Ziraat F. arkası (12a), açıklık alan, 514 m, 26.4.2016, S.Yağmur 119, KASOF 862; KSÜ Ziraat F. arkası (12b), açıklık alan, $513 \mathrm{~m}, 28.4 .2016$, S.Yağmur 147, KASOF 863; KSÜ Ziraat F. Terasları civarı (11b), yol kenarı, $510 \mathrm{~m}, 1.5 .2016$, S.Yağmur 177, KASOF 864; KSÜ İlahiyat F. arkası (22d), açıklık alan, 533 m, 12.04.2017, S.Yağmur 259, KASOF 865, Euro-Sib. el. 251. Xanthium strumarium L. subsp. cavanillesii (Schouw) D. lã-ve et P. Dansereau : Pitrak

KSÜ Kafeterya altı (14d), açıklık alan, 525 m, 01.06.2017, S.Yağmur 376, KASOF 866

\section{B. LILIOPSIDA \\ I. Arecidae \\ I.1. Arecales \\ 62. Arecaceae}

252. Washingtonia robusta $\mathrm{H}$.Wendl. : Vaşingtonya

KSÜ Rektörlük binası civarı (24b), peyzaj düzenlemeleri, $544 \mathrm{~m}$, 18.05.2017, S.Yağmur 352, KASOF 867, Egzotik.

$$
\text { I.2. Cyperales }
$$

63. Poaceae

253. Aegilops columnaris Zhukovsky : Buğdayanası 
KSÜ Kafeterya altı (14d), açıklık alan, 525 m, 23.4.2016, S.Yağmur 88, KASOF 868; KSÜ Ziraat F. arkası (12b), açıklık alan, $513 \mathrm{~m}$, 28.4.2016, S.Yağmur 135, KASOF 869, Ir.-Tur. el.

254. Avena barbata Pott ex Link subsp. barbata: Narin yulaf

KSÜ Kafeterya altı (14d), açıklık alan, 522 m, 23.4.2016, S.Yağmur 76, KASOF 870, Medit. el.

255. A. sterilis L. subsp. ludoviciana (Durieu) Gillet et Magne : Sifan KSÜ Orman F.- İİBF arası (24a), açıklık alan, 543 m, 18.4.2016, S.Yağmur 22, KASOF 871.

256. Bromus sterilis L. : Sağır ilcan

KSÜ Orman F.- İİBF arası (24a), açıklık alan, 536 m, 18.4.2016, S.Yağmur 21, KASOF 872.

257. B. tectorum L. subsp. tectorum : Kır bromu

KSÜ Ziraat F. civarı (12c), yol kenarı, 520 m, 10.04.2017, S.Yağmur 251, KASOF 873

258. Cortaderia selloana (Schultes et Schultes Fil.) Aschers. et Graebn. : Pampasotu

KSÜ Kafeterya üst yol (24b), açıklık alan, 546 m, 24.04.2015, S.Yağmur 286, KASOF 874. Egzotik.

259. Cynodon dactylon (L.) PERS. var. dactylon : Köpekdişi

KSÜ Spor salonu arkası (28a), açıklık alan, 529 m, 01.06.2017, S.Yağmur 366, KASOF 875.

260. C. dactylon (L.) Pers. var. villosus Regel

KSÜ Ziraat F. arkası (12b), açıklık alan, 507 m, 01.06.2017, S.Yağmur 367, KASOF 876.

261. Digitaria sanguinalis (L.) Scop. : Kızıl çatalotu

KSÜ İlahiyat F.-Alakart arası (23d), orman içi açıklık, $532 \mathrm{~m}$, 01.06.2017, S.Yağmur 368, KASOF 877.

262. Echinaria capitata (L.) Desf. : Dikenbaşotu

KSÜ Orman F.- İ̈BF arası (23a), açıklık alan, 533 m, 24.04.2015, S.Yağmur 289, KASOF 878.

263. Hordeum bulbosum L. : Boncuk arpa

KSÜ Ziraat F. arkası (12b), açıklık alan, 513 m, 28.4.2016, S. Yağmur 141, KASOF 879

264. H. murinum L. subsp. glaucum (Steudel) Tzvelev : Duvar arpas1 KSÜ Yabancı Diller F. civarı (22c), yol kenarı, 540 m, 20.4.2016, S.Yağmur 36, KASOF 880.

265. H. spontaneum C. Koch : Yabani arpa

KSÜ Kafeterya altı (14d), açıklık alan, 522 m, 23.4.2016, S.Yağmur 78, KASOF 881, Ir.-Tur. el.

266. Imperata cylindrica (L.) Raeuschel : Kırmızı uçlu saz

KSÜ Ziraat F. arkası (12b), açıklık alan, 509 m, 07.06.2017, S.Yağmur 383, KASOF 882.

267. Phalaris brachystachys Link : Kanyas

KSÜ Yabancı Diller F. civarı (22b), açıklık alan, 540 m, 11.5.2016, S.Yağmur 210, KASOF 883, Medit. el.

268. $P$. paradoxa L.

KSÜ Kafeterya altı (14d), açıklık alan, 525 m, 23.4.2016, S.Yağmur 90, KASOF 884.

269. Phragmites australis (Cav.) Trin. ex Steudel : Kamış

KSÜ Ziraat F. arkası (12b), açıklık alan, 513 m, 24.10.2016,

S.Yağmur 241, KASOF 885, Euro-Sib. el.

270. Poa pratensis L. : Salkımotu

KSÜ Orman F--i்̇BF arası (24a), açıklık alan, 543 m, 18.4.2016, S.Yağmur 19, KASOF 886.

271. Setaria glauca (L.) P. Beauv. : Siçansaçı

KSÜ İlahiyat F.-Alakart arası (23d), orman içi açıklık, $530 \mathrm{~m}$, 01.06.2017, S.Yağmur 374, KASOF 887.

272. Sorghum halepense (L.) Pers. var. halepense : Ekin süpürgesi KSÜ Orman F.-İ̈BF arası (23b), yol kenarı, 536 m, 8.6.2016, S.Yağmur 232, KASOF 888; KSÜ Ziraat F. arkası (12b), açıklık alan, $513 \mathrm{~m}, 24.10 .2016$, S.Yağmur 246, KASOF 889.

273. S. halepense (L.) Pers. var. muticum (Hackel) Grossh

KSÜ Ziraat F. arkası (12b), açıklık alan, 513 m, 28.4.2016, S.Yağmur

131, KASOF 890; KSÜ Kafeterya altı (14a), yol kenarı, 514 m, 23.4.2016, S.Yağmur 64, KASOF 891.
II. Liliidae

II.1. Liliales

64. Liliaceae

274. Allium sp. : Soğan

KSÜ Ziraat F. Terasları civarı (11a), açıklık alan, 500 m, 1.5.2016, S.Yağmur 199, KASOF 892.

275. Asphodelus aestivus Brot. : Kirgiçkökü : Çirişağusu

KSÜ İlahiyat F. arkası (22c), açıklık alan, $529 \mathrm{~m}, 12.04 .2017$, S.Yağmur 255, KASOF 893, Medit. el.

276. Ornithogalum umbellatum L. : Akylldız

KSÜ Spor sahası etrafı (26d), açıklık alan, $534 \mathrm{~m}, 27.04 .2017$, S.Yağmur 273, KASOF 894.

277. Yucca gloriosa L. : Avize ağacı

KSÜ Rektörlük binası civarı (24a), peyzaj düzenlemeleri, $545 \mathrm{~m}$, 18.05.2017, S.Yağmur 354, KASOF 895, Egzotik.

\section{Iridaceae}

278. Gladiolus italicus Miller : Kılıçotu

KSÜ Kafeterya altı (14d), açıklık alan, 522 m, 23.4.2016, S.Yağmur 81, KASOF 896; KSÜ Ziraat F. Terasları civarı (11a), orman kenarı, 510 m, 1.5.2016, S.Yağmur 196, KASOF 897.

279. Ixiolirion tataricum (Pallas) Herbert subsp. montanum (Labill.) Takht. : Köpekotu

KSÜ Spor salonu arkası (28a), açıklık alan, 529 m, 30.04.2015, S.Yağmur 295, KASOF 898; KSÜ Spor sahası etrafı (22c), açıklık alan, 538 m, 27.04.2017, S.Yağmur 275, KASOF 899. 